\title{
Biological Stability of Water-Based Cutting Fluids: Progress and Application
}

\author{
Lizhi Tang ${ }^{1}$, Yanbin Zhang ${ }^{1}$, Changhe $\mathrm{Li}^{1 *}$, Zongming Zhou ${ }^{2}$, Xiaolin $\mathrm{Nie}^{3}$, Yun Chen ${ }^{4}$, Huajun $\mathrm{CaO}^{5}$, \\ Bo Liu ${ }^{6}$, Naiqing Zhang ${ }^{7}$, Zafar Said ${ }^{8}$, Sujan Debnath ${ }^{9}$, Muhammad Jamil ${ }^{10}$, Hafiz Muhammad Ali $^{11}$ and \\ Shubham Sharma ${ }^{12}$
}

\begin{abstract}
The application of cutting fluid in the field of engineering manufacturing has a history of hundreds of years, and it plays a vital role in the processing efficiency and surface quality of parts. Among them, water-based cutting fluid accounts for more than $90 \%$ of the consumption of cutting fluid. However, long-term recycling of water-based cutting fluid could easily cause deterioration, and the breeding of bacteria could cause the cutting fluid to fail, increase manufacturing costs, and even endanger the health of workers. Traditional bactericides could improve the biological stability of cutting fluids, but they are toxic to the environment and do not conform to the development trend of low-carbon manufacturing. Low-carbon manufacturing is inevitable and the direction of sustainable manufacturing. The use of nanomaterials, transition metal complexes, and physical sterilization methods on the bacterial cell membrane and genetic material could effectively solve this problem. In this article, the mechanism of action of additives and microbial metabolites was first analyzed. Then, the denaturation mechanism of traditional bactericides on the target protein and the effect of sterilization efficiency were summarized. Further, the mechanism of nanomaterials disrupting cell membrane potential was discussed. The effects of lipophilicity and the atomic number of transition metal complexes on cell membrane penetration were also summarized, and the effects of ultraviolet rays and ozone on the destruction of bacterial genetic material were reviewed. In other words, the bactericidal performance, hazard, degradability, and economics of various sterilization methods were comprehensively evaluated, and the potential development direction of improving the biological stability of cutting fluid was proposed.
\end{abstract}

Keywords: Cutting fluid, Microorganism, Bactericide, Sterilization

\section{Introduction}

Cutting fluids are widely used in machining processes, such as turning, milling, planing, grinding, and forming manufacturing processes, and they have functions, such as cooling, lubrication, rust prevention, and chip removal [1-3]. The use of cutting fluid is of great importance because it could reduce the cutting force and temperature during the cutting process and improve the surface quality of the workpiece and tool life $[4,5]$. In accordance

\footnotetext{
*Correspondence: sy_lichanghe@163.com

1 School of Mechanical and Automotive Engineering, Qingdao University of Technology, Qingdao 266520, China

Full list of author information is available at the end of the article
}

with the composition of the cutting fluid, it could be divided into oil-based cutting fluid and water-based cutting fluid [6,7]. Oil-based cutting fluid is prepared with oil as the base fluid. It has high biological stability but insufficient cooling performance $[8,9]$. It is mostly used for slow processing or heavy-duty processing. For parts processing, the usage only accounts for a small part of the total usage of cutting fluid $[10,11]$. The use ratio of waterbased cutting fluid is as high as more than $90 \%$, and water is used as the base fluid, which has good cooling performance $[12,13]$. Meanwhile, to take into account the functions of lubrication, cleaning, and rust prevention, various additives are also added [14, 15]. However, the moisture in the water-based cutting fluid and the high 
trace elements in the additives could easily lead to the reproduction of microorganisms, hence the serious biological stability problems during usage $[16,17]$.

Water-based cutting fluid could breed many bacteria or fungi during use $[18,19]$. The bacteria could decompose additives in the cutting fluid, destroy its stability, and reduce its performance. Fungi may also block the circulation system of the cutting fluid [20,21]. The proliferation of bacteria could produce biofilms [22-24]. The existence of biofilms provides better conditions for bacteria to multiply, causing a vicious circle [25-27]. A more serious problem is that endotoxins, exotoxins, and bioaerosols produced by bacteria in water-based cutting fluids could cause respiratory diseases and affect the health of workers [28-30]. The harm of microorganisms to cutting fluids and human health has always been a problem in the field of mechanical processing [31-33]. Frequent replacement of cutting fluids due to microbial reproduction problems could inevitably cause a great waste of resources, contrary to the current green and sustainable development $[34,35]$. Therefore, people have come up with various methods to inhibit the reproduction of microorganisms in the cutting fluid; the most commonly used is the use of biological bactericides. These bactericides could inactivate bacteria by destroying the cell membrane of microorganisms, destroying the structure of microbial proteins, and interfering with DNA synthesis [36, 37]. The types of bactericides commonly used in the industry include formaldehyde releasers, isothiazolinones, boric acids, and amines [38]. However, these kinds of bactericides are generally irritating and allergenic, and they could not avoid the harm to human health while killing bacteria [39, 40]. On the basis of the consideration of sterilization effect and human health, some scholars have explored new bactericides or sterilization methods used in cutting fluids. Different kinds of nanomaterials [41-43], transition metal complexes [4446], and other new bactericides were studied, including physical sterilization methods, such as ultraviolet (UV) sterilization [47], ozone sterilization [48, 49], and finebubble [50] sterilization.

Low-carbon manufacturing is inevitable and the direction of sustainable development. Therefore, the use of environmental friendly methods to improve the biological stability of water-based cutting fluids is a current research hotspot. In this article, the mechanism of action of additives and microbial metabolites was introduced. Then, the denaturation effects of traditional bactericides on target proteins and their bactericidal efficiency were reviewed. The lipophilicity of nanomaterials and transition metal complexes and their influence on cell membrane penetration were discussed. The destructive effects of UV rays and ozone on bacterial genetic material and their bactericidal effects were explored. Through the analysis, conclusions were drawn and prospects for the future development direction of the stability of waterbased cutting fluids were elucidated. Figure 1 shows the structure of this article.

\section{Cutting Fluid}

Machining is widely used in automotive, aerospace, and other fields, and it is the basis of manufacturing industry. Cutting fluid is an indispensable element in the machining manufacturing industry [51-53]. The use of cutting fluid could reduce the cutting temperature, reduce the friction between the tool and the workpiece, extend the life of the tool, and improve the processing efficiency [54-56].

\subsection{Function}

Cutting fluid has the functions of cooling, lubrication, cleaning and rust prevention $[57,58]$. Cooling effect: in the process of metal processing, the friction between the tool and the workpiece, the friction between the tool and the chip, the deformation of the metal, etc. could generate a huge amount of heat. Too much heat in the processing area could easily cause burns between the tool and workpiece, thus affecting the accuracy and smoothness of the workpiece surface [59-61]. In the metal processing process, the cutting fluid could realize the heat exchange effect in the metal cutting process through heat conduction and heat convection. Then, the heat in the cutting zone is taken away by continuous flow and vaporization to reduce the tool temperature [62-64], thereby improving the stability of the tool during the cutting process and the machining accuracy of the workpiece, reducing tool wear, and extending tool life [65-67].

Lubrication: during the machining process, the toolworkpiece and tool-chip interface could produce strong friction [68-70]. The cutting fluid penetrates into the

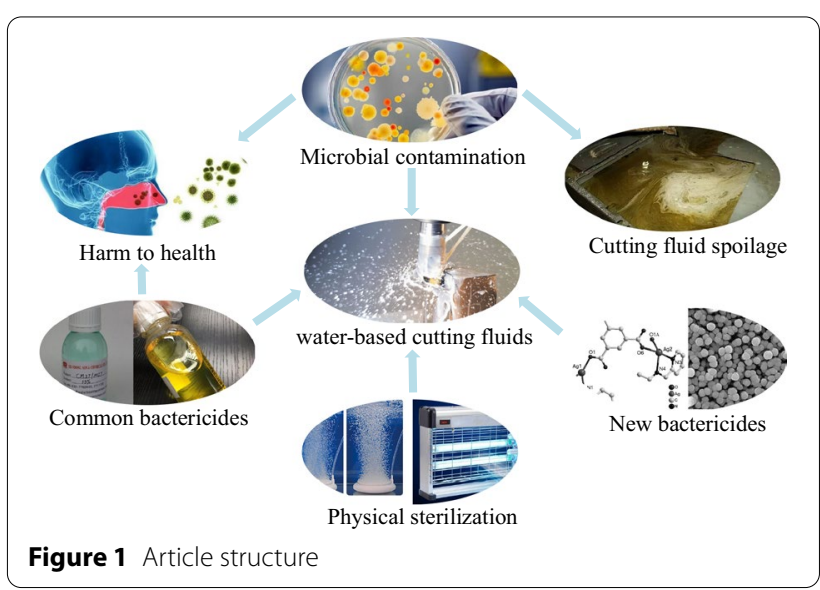


cutting area to form a lubricating film (this kind of lubricating film could be divided into adsorption film and reaction film. The active material in the cutting fluid is adsorbed on the surface of the workpiece to form an adsorption film, and the additive in the cutting fluid chemically reacts with the workpiece to form a reactive film [71-73]), thereby reducing the friction between tool workpiece and tool chips, reducing energy consumption in the cutting process, reducing cutting force, and extending tool life [74-76].

Cleaning function: the chips produced in metal processing, dust, and oil in the air are adsorbed on the surface of tools and workpieces. This phenonenon has a certain effect on processing [77-79]. Cutting fluids could remove all kinds of dirt during the flow process to clean workpieces and tools [80, 81].

\subsection{Classification}

Cutting fluids could be divided into two groups in accordance with their composition: oil-based and waterbased groups [82, 83], as shown in Figure 2.

The main components of oil-based cutting fluids include animal and vegetable oils and mineral oils. Oilbased cutting fluids were originally produced from animal and vegetable oils. However, because animal and vegetable oils are prone to corruption during use, they were gradually replaced by mineral oils $[85,86]$. Oilbased cutting fluid has good lubricity. However, shortcomings exist, such as oil mist that is easy to produce and fire that is easy to catch during use [87]. Therefore, oilbased cutting fluids are mainly used for processing large or heavy parts. Meanwhile, because oil-based cutting fluid has good lubricating performance but poor cooling performance, it is generally used for low-speed cutting. Water-based cutting fluid is often used in high-speed cutting to ensure the machining accuracy.

Water-based cutting fluids could also be divided into emulsions, semi-synthetic fluids [10, 11], and synthetic fluids. Emulsion is formed by mixing base oil and water in a certain proportion. Its oil content is $60 \%-90 \%$, the particle size is $1-10 \mu \mathrm{m}$, and its appearance is milky white [77, 88]. Emulsion has lubrication and cooling functions. However, its stability is poor, and it is easy to breed bacteria in the process of use [60]. Semi-synthetic fluid integrates the advantages of emulsion and synthetic fluid. Compared with emulsion, it adds more surfactants, which make the oil droplet size smaller, ranging from $0.05 \mu \mathrm{m}$ to $0.1 \mu \mathrm{m}$. Therefore, it is more stable and less prone to deterioration. The appearance of semi-synthetic liquid is transparent or translucent. Therefore, observing the condition of the cutting area during machining is easy $[85,89]$. The synthetic solution does not contain any oil. It uses other additives, such as water-soluble synthetic grease, to achieve its lubricating properties [65]. Its appearance is transparent, and it has excellent cooling performance. However, the machine tool is prone to rust after it is used [90], as shown in Table 1.

With the improvement of processing conditions; the call for energy saving and emission reduction; and the research on additives, such as lubricants, corrosion inhibitor, and bactericides, water-based cutting fluids have been developed rapidly due to their excellent cooling performance and low cost [91, 92]. In 2018, waterbased cutting fluids have accounted for $90 \%$ of the total global demand for cutting fluids [12].

Table 1 The difference between different types of cutting fluids

\begin{tabular}{llll}
\hline Type & Oil content $(\%)$ & Particle size $(\boldsymbol{\mu m})$ & Appearance \\
\hline Oil-based & 100 & - & Transparent \\
Emulsion & $60-90$ & $>1$ & Milky \\
& & $0.1-1$ & Milky blue \\
Semi-synthetic & $10-30$ & $0.05-0.1$ & Translucent gray \\
& & $<0.05$ & Transparent \\
Synthetic & 0 & - & Transparent \\
\hline
\end{tabular}

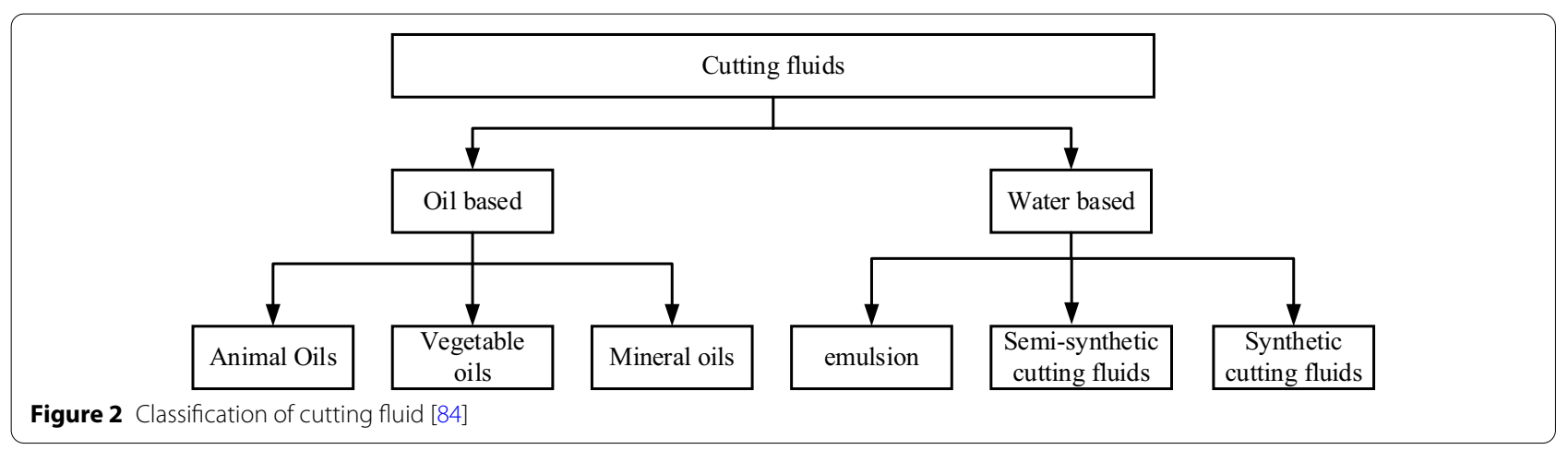




\subsection{Additives}

Water-based cutting fluid is made by mixing mineral oil or synthetic oil with water in a certain proportion. It is a coolant and lubricant widely used in processing. Adding various additives to the cutting fluid is often necessary to enhance the performance of the cutting fluid and prolong its service life. Some examples, such as oily agents, extreme-pressure agents, emulsifiers, defoamers, corrosion inhibitors, and bactericides, are shown in Table 2.

The oily agent could form an adsorption film on the friction interface, thereby reducing the friction in the cutting zone. The commonly used oily agents include animal and vegetable oils, higher fatty acids, amines, and amide compounds. However, when the temperature of the friction interface increases, the activity of the molecules also increases. Therefore, the adsorption strength of the oil film decreases, resulting in the failure of the oil-based agent. Extreme-pressure additives contain organic compounds, such as phosphorus, sulfur, and chlorine. They react with metal surface and form chemical reaction film under high temperature and high pressure boundary lubrication. Therefore, they could induce a lubricating effect when the oily agent fails $[14,15]$.

After machining, a metal workpiece retains water on the surface, and it easily rusts after contacting with oxygen. Therefore, adding corrosion inhibitor to ensure that the workpiece does not rust in a period of time is necessary [94]. Corrosion inhibitors could be divided into anode corrosion inhibitors, cathodic corrosion inhibitors, and mixed corrosion inhibitors [95]. Anodic corrosion inhibitors could form oxide film on the surface of metal workpiece, thus delaying workpiece corrosion [96]. Cathodic corrosion inhibitors could be deposited on the cathode area to prevent electrons from flowing from the anode to the cathode $[97,98]$. The mixed inhibitors could form a film on the surface of the workpiece to prevent corrosion. The mixed inhibitor is a polar material. Its head is adsorbed on the surface of the workpiece, and the nonpolar tail is closely arranged perpendicular to the workpiece, forming a tight protective film. In addition, the nonpolar tail could absorb hydrocarbons to increase the thickness of the protective film, as shown in Figure 3 [94].

During the processing, due to the presence of surfactants in the cutting fluid, the cutting fluid tends to foam when it impacts the workpiece or the machine tool. The gas in the foam reduces the cooling performance of the cutting fluid. Thus, adding a defoaming agent is necessary. The defoaming agent plays an important role by inhibiting foam formation, thinning the foam film to the crack, and making the foam easier to fuse to accelerate bubble rupture.

Emulsifiers are mostly surfactants, one end of which is hydrophobic, and the other end is hydrophilic. It could form a molecular film at the interface of oil and water, reduce its surface tension, and make oil and water form a stable emulsion $[99,100]$, as shown in Figure 4.

Due to the emergence of various additives, the performance of water-based cutting fluids has been greatly improved. However, the cutting fluid is easily attacked by microorganisms. Every year, a large amount of cutting fluid is corrupted and deteriorated due to the proliferation of microorganisms, resulting in waste of energy and resources. Therefore, the microbial spoilage of cutting fluid needs to be solved urgently.

\section{Biological Stability Issues in Water-Based Cutting Fluids}

Water-based cutting fluids are extremely susceptible to microbial contamination. During the use of cutting fluid, the bacteria and microorganisms that exist in the water, on the workpiece, on the skin of the worker,

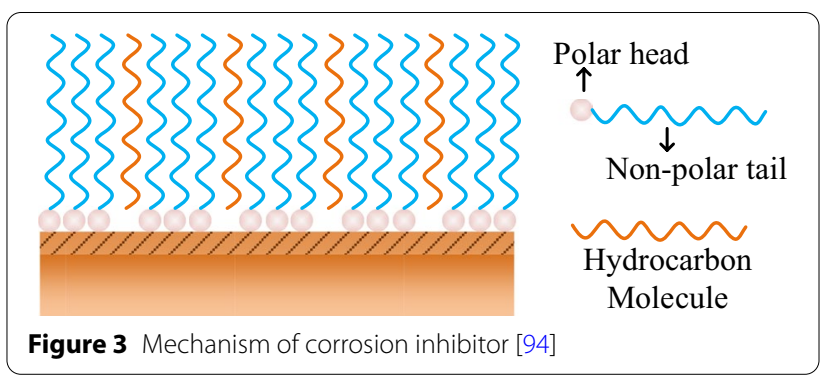

Table 2 Additives [93]

\begin{tabular}{lll}
\hline Category & Additive & Effect \\
\hline Oily agent, extreme pressure agent & Sulfur, phosphorus, chlorine and other organic compounds & $\begin{array}{c}\text { Enhance the performance of the } \\
\text { lubricating film }\end{array}$ \\
Corrosion inhibitor & Sodium nitrite, phenethanolamine & Prevent corrosion of the workpiece \\
Anti-foam & Dimethyl silicone oil, emulsified silicone oil & Reduce or eliminate foam \\
Emulsifier & Sodium Petroleum Sulfonate & Emulsion formation \\
Bactericide & Formaldehyde-releasers, isothiazolinone & Inhibit bacterial reproduction
\end{tabular}




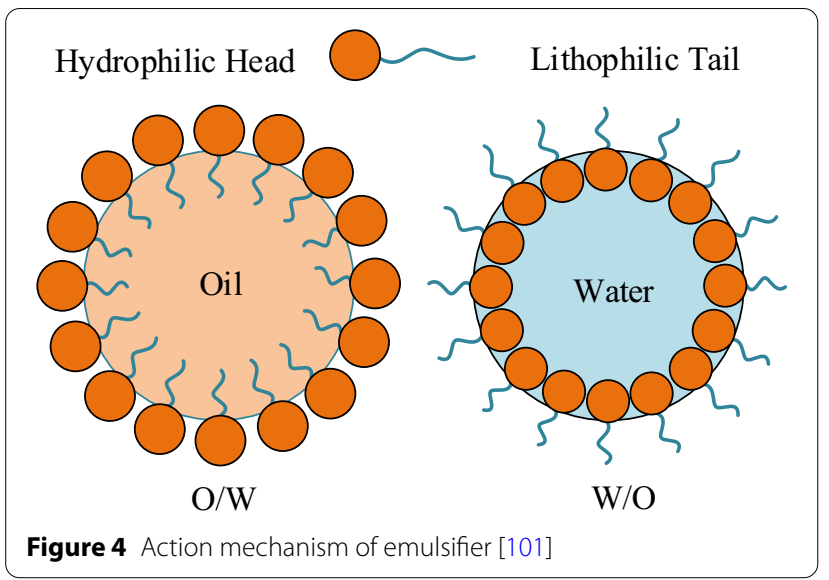

in the remaining liquid before the machine tool, and in the air are mixed into it [16]. The cutting fluid also contains organic matter needed for microbial reproduction; nitrogen, phosphorus, sulfur, and other trace elements in various additives; and water. The flow of cutting fluid makes it have more oxygen. All these phenomena provide favorable conditions for microbial reproduction and metabolism [102]. The metabolites of one microorganism in the cutting fluid may also become a food source for another organism to accelerate the propagation speed of microorganisms. In addition, the water-based cutting fluid in the machine tool is a complex system. The species and quantity of microorganisms change continuously during the use of cutting fluid [103].

\subsection{Types of Microorganisms}

The microorganisms in cutting fluid include bacteria and fungi. Bacteria could be divided into aerobic bacteria and anaerobic bacteria, such as Escherichia coli, Staphylococcus aureus, pneumococcus, Salmonella typhi, Pseudomonas aeruginosa, Pseudomonas oleifera, and sulfate reducing bacteria. Fungi are divided into yeast and mold, including Penicillium, cephalosporin, Aspergillus, and Fusarium. Facultative anaerobes are special and important biodegradants. When sufficient oxygen is present, facultative anaerobes behave like aerobic bacteria. When oxygen is not sufficient to support aerobic metabolism, they behave like anaerobic bacteria. Especially in biofilm community, facultative anaerobic bacteria consume oxygen, thus creating conditions suitable for anaerobic bacteria to survive [104].

In addition, because bacteria differ in accordance with the chemical composition, shape, and metabolic substances of their cell walls and respond differently to staining, they could also be divided into Gram-positive and Gram-negative bacteria [105]. Gram-positive bacteria have a thicker cell wall, and multiple peptidoglycan layers

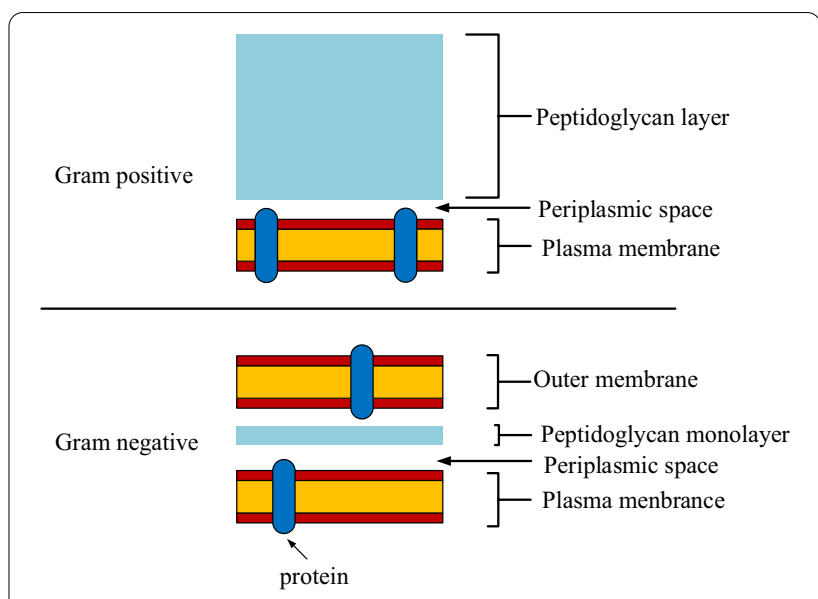

Figure 5 Gram-positive and Gram-negative cell wall structure [118]

are present within this cell wall. The cell wall of Gramnegative bacteria is thinner, with a characteristic outer membrane [50], as shown in Figure 5.

The number of microorganisms in cutting fluid is the key to affecting the cutting fluid performance and judge whether replacement of cutting fluid is necessary. Some scholars have found through research that the microbial concentration of contaminated cutting fluid ranges from $10^{4}$ colony forming units (CFU)/mL to $10^{10} \mathrm{CFU} /$ $\mathrm{mL}$ [106]. Shennan's study found that the bacteria in water-based cutting fluids were mainly Gram-negative bacteria with a microbial concentration of approximately $10^{8} \mathrm{CFU} / \mathrm{mL}$ [103]. Some scholars further analyzed the $16 \mathrm{~S}$ ribosomal DNA metagenome of microorganisms in used cutting fluid. They found that a large number of bacteria belonged to Pseudomonas, and the diversity of Pseudomonas bacteria was low [107, 108]. Pseudomonas is a kind of Gram-negative aerobic bacteria, which is the most common genus in cutting fluid, and it widely exists in soil and water environment [107].

In addition, the microbial species in the cutting fluid change with the degree of pollution. When the pollution is not serious, the spoilage bacteria are mainly Pseudomonas $[103,109]$. When the microbial contamination reaches $10^{8} \mathrm{CFU} / \mathrm{mL}$, facultative anaerobes are the main bacteria. In the last stage of cutting fluid decay, the $\mathrm{pH}$ value of the cutting fluid decreases and the bacterial diversity increases. Various Gram-negative bacteria could be isolated from cutting fluid, including Acinetobacter, Achromobacter, and Alcaligenes. In addition, cutting fluid is contaminated by other common bacteria, such as Gram-positive bacteria (Micrococcus, Staphylococcus, Streptococcus, and Bacillus) and atypical mycobacteria [109-114]. Yeasts and filamentous fungi could also contaminate cutting fluid, but these are less abundant 
$\left(10^{2}-10^{4} \mathrm{CFU} / \mathrm{mL}\right)[36,115,116]$. Molds are mostly adhered to machine tool walls or pipes [117].

When the microorganisms in cutting fluid propagate to a certain extent, many microorganisms like to gather to form a multicellular community. This multicellular community is called biofilm [25-27], as shown in Figure 6. Biofilms appear as a slimy film or flocculus

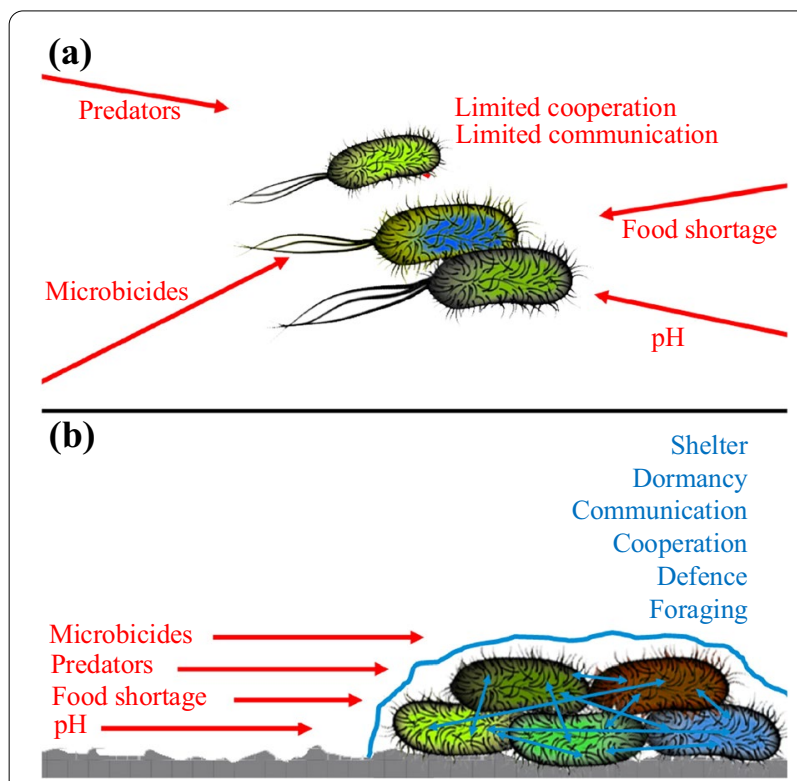

Figure $\mathbf{6}$ a Some bacteria are in a free state, $\mathbf{b}$ A large number of bacteria aggregates to form a biofilm [121] in a liquid gathered on a moist wall surface, as shown in Figure 7. Biofilms also have complex structures, such as channels for fluid and nutrient transport, which could provide a sanctuary for microorganisms. Oxygen concentration gradient, organic matter concentration gradient, and $\mathrm{pH}$ value gradient could be formed at different positions of biofilm. Therefore, aerobic and anaerobic bacteria and acidophilic and acidophilic bacteria coexist. The interaction of microorganisms in the biofilm could also make the microbial resistance to bactericides 1000 times higher than before [119]. Some of them could go into dormancy until the external environment is suitable for their survival [120].

When the environment is suitable, the microbial species mentioned above could split once every $30 \mathrm{~min}$ or so. The number increases in geometric progression. When the machine is shut down, the cutting fluid is still. The growth of aerobic bacteria consumes the oxygen in the cutting fluid. When oxygen is not sufficient, anaerobic bacteria multiply. Anaerobic bacteria, such as sulfate-reducing bacteria and Citrobacter, could decompose sulfur groups in sulfate. Anaerobes generate hydrogen sulfide, which is dissolved in cutting fluid, by metabolism. When the machine tool is started again, hydrogen sulfide will be released, causing peculiar smell around the machine tool. As the reproduction speed of anaerobic bacteria is lower than that of aerobic bacteria, when the odor appears, it is a sign of severe spoilage of the cutting fluid, as shown in Figure 8.
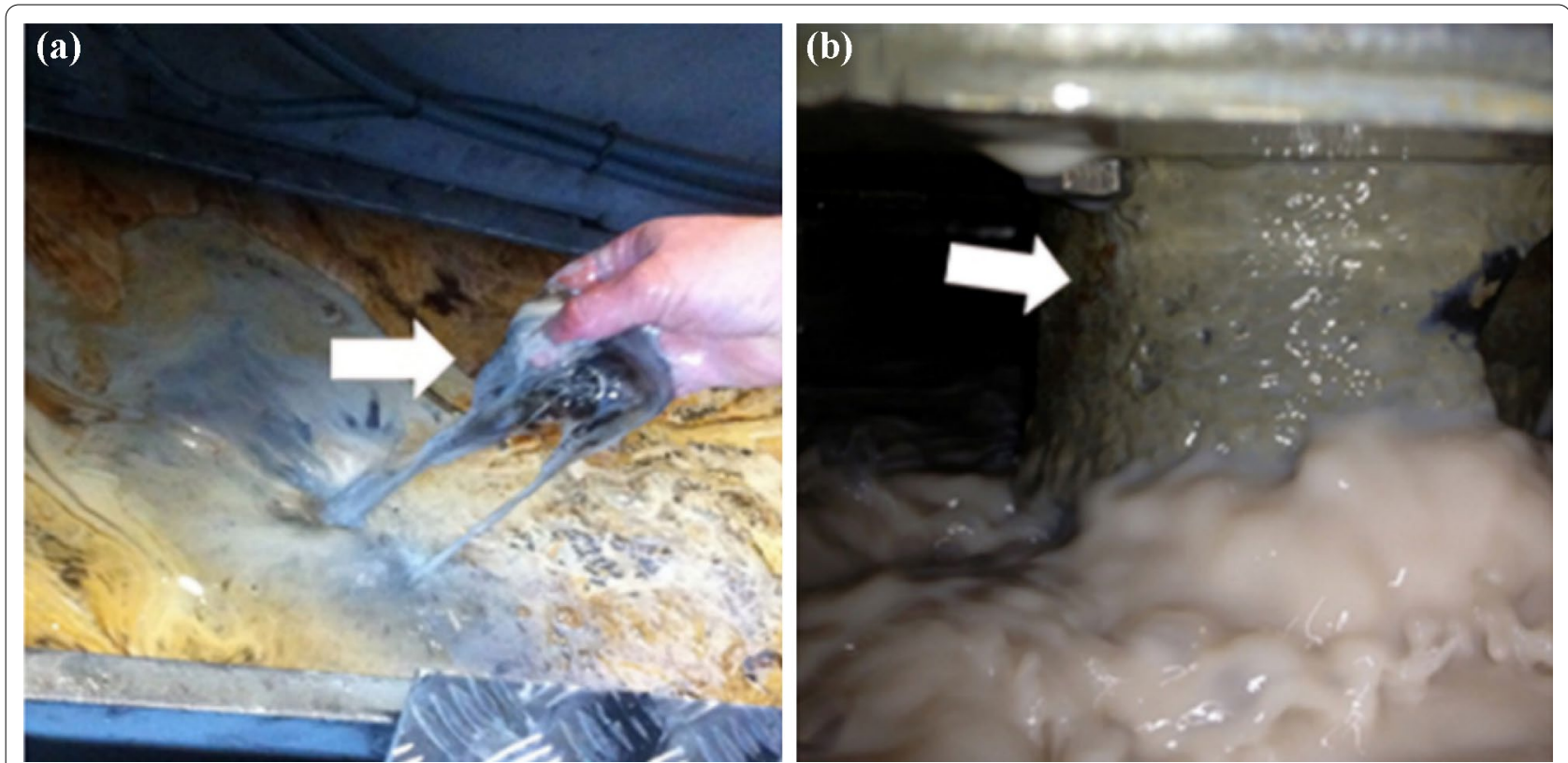

Figure 7 a Newly formed biofilm is easier to remove, b Mature biofilm is more difficult to remove [121] 


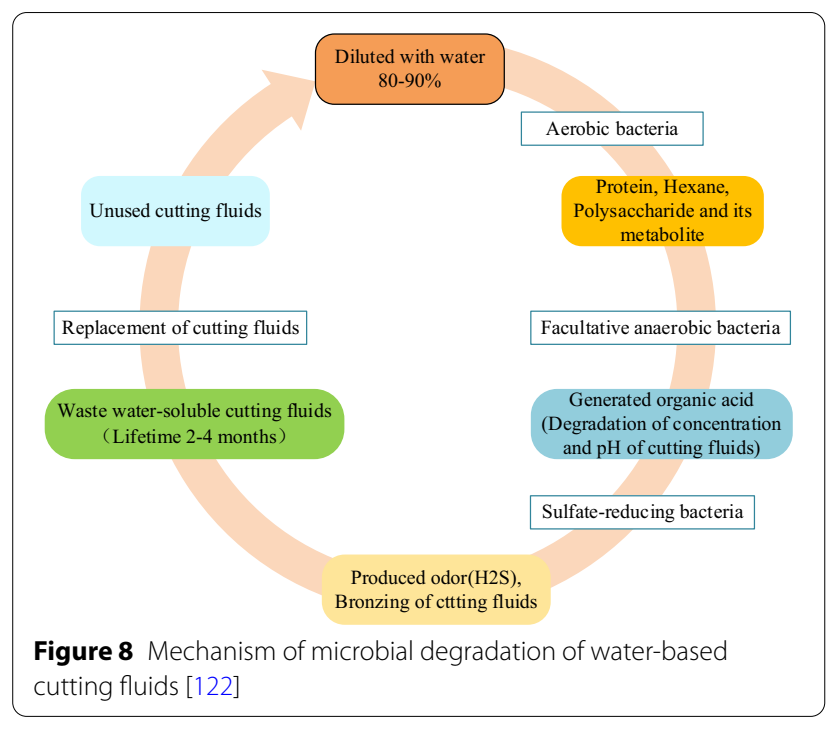

\subsection{Microbial Influence}

The microorganisms in cutting fluid could cause irreversible damage to the cutting fluid and machine tools. Bacteria decompose the emulsifier in the cutting fluid. When the emulsifier is consumed to a certain extent, the stability of the cutting fluid could be destroyed. Oil could precipitate out of this stable state, thereby affecting the lubricating performance of the cutting fluid. It could also reduce the $\mathrm{PH}$ value of the cutting fluid, thereby reducing its rust-proof performance [123]. It could make unsaturated bonds in the cutting fluid become saturated bonds, remove side chains from complex molecules, and shorten chain length [122], thus reducing the function of cutting fluid. It could also cause malodor, reduce tool life (metal corrosion), increase friction heat, increase energy consumption, and reduce the surface finish of the workpiece [124].

Moulds and fungi could change the color of cutting fluid when they reproduce in large quantities. Lumps that block the circulation system of the cutting fluid, overload the circulation system, and have a certain effect on the filter and the liquid supply pipeline could also be present [124]. Meanwhile, molds and fungi undergo spore reproduction. Spore has very strong viability, high heat, and dry resistance. The mold must be removed with the spores to completely remove it. Thus, removing molds is more difficult than removing bacteria [125].

Microbes also aggregate to form biofilms, as shown in Figure 9. Biofilms are complex microbial communities growing in cutting fluids. They could be composed of various organisms, including Gram-positive and -negative bacteria and yeast. Biofilms could generate mucus, causing filter blockage, product contamination, and equipment damage [106]. Biomembranes could also create conditions that promote electrochemistry. Electrons could flow from the anode area covered by the biofilm to the cathode area on the metal surface, forming an electric current and corroding the metal. The common form of corrosion caused by microorganisms is pitting [126]. In addition, most of the microorganisms produce acidic metabolites (mainly C1-C6 carboxylic acids) [127]. These organic acids are not very corrosive. However, they could react with inorganic chlorides to form weak organic bases and strong

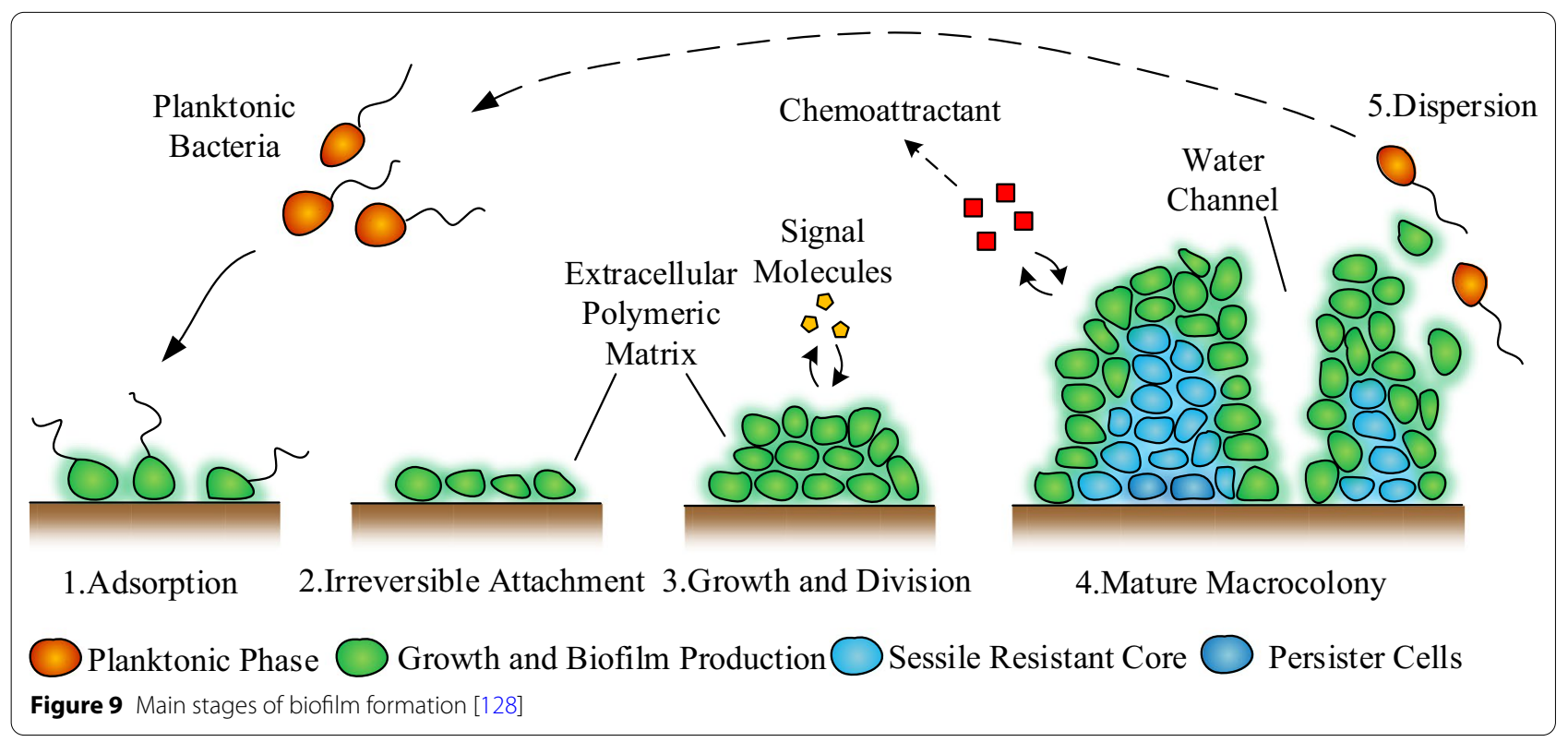


inorganic acids. They cause metals to be further corroded, especially hydrochloric acid (Eq. (1)) [127]:

$$
\mathrm{R}-\mathrm{COOH}+\mathrm{NaCl} \rightarrow \mathrm{R}-\mathrm{COONa}+\mathrm{HCl} .
$$

In addition, the microorganisms in cutting fluid could have some effects on human physical health. The damage to workers' health is mainly allergic diseases. The Mycobacterium cells and their metabolites in cutting fluid may cause a series of inflammations ranging from mild rhinitis to fatal allergic pneumonia [129]. Hydrogen sulfide, the metabolite of anaerobic bacteria, is an odorous and highly toxic gas. It could cause toxicity to human lung, heart, and other organs. Various pathogens may also cause infection in workers' wounds [129].

Cutting fluid produces bio-aerosol during use. Bioaerosols are air-suspended particles containing organisms or their metabolites. These particles are usually toxic or sensitive [130]. Toxic aerosols are further divided into exotoxins and endotoxins. Exotoxins are secreted by organisms, mainly diffusion proteins secreted by Gram-positive bacteria into the surrounding medium. Endotoxin is a structural component of organisms and an inducer of inflammatory cytokines [131], as shown in Figure 10. The most common endotoxin that workers are exposed to is a lipopolysaccharide. It is found in the outer membrane of the cell wall of Gram-negative bacteria. Exposure of endotoxin produced by cell wall rupture to the air may cause respiratory disorders and narrow the human bronchial tubes. It could increase the release of pro-inflammatory cytokines, causing workers to produce fever and respiratory symptoms [132]. It could also cause acute or chronic lung inflammation, including chronic sputum expectoration, lung function decline, fatigue, atherosclerosis and even toxic shock $[28,29]$.

The hazards caused by microorganisms are not estimable, and measures must be taken to control the propagation of microorganisms in cutting fluid. Among them, the main factors affecting microorganism multiplication are $\mathrm{pH}$ value, temperature, oil content, and water quality of water-based cutting fluids. Therefore, to prevent the harm caused by microorganisms, the following points must be started. (1) Dilute the cutting fluid by using tap or demineralized water, with minimal use of water with high hardness. (2) Try to avoid the machine tool shutdown for a long time to keep the cutting fluid under flow and avoid heavy multiplication of anaerobes. (3) Clean the machine tools and their surroundings before cutting fluid injection to avoid carrying bacteria at the beginning. (4) Add a fungicidal mold inhibitor to the cutting fluid and replenish it in a timely manner. Among them, the most common and effective method to control the growth of microorganisms in cutting fluids is to use bactericides. It could control microorganisms within a certain number range, thus extending the useful life of cutting fluid.

\section{Bactericides in Cutting Fluid}

\subsection{Commonly Used Bactericides}

The effect of Bactericides on microorganisms is generally divided into three stages: physicochemical absorption of the bactericides on the microbial surface, penetration of the bactericides into the cells, and the effect of the bactericides on the target site. However, not all bactericides need to penetrate inside the cell to function. Part of the bactericides could act on one or more target sites, such as cell membranes, intracellular proteins, and nucleic acids (NAs). In addition, due to the diversity of microorganisms, each bactericide has its own sterilization mechanism, such as obstructing bacterial respiration, affecting bacterial metabolic processes, inhibiting protein synthesis, damaging the cell wall, and impeding NA formation (Table 3).

The bactericides used in cutting fluid should meet the criteria of having broad spectrum, low concentration availability, stability, noncorrosive to metals, non contaminating environment, cheap, not causing intensive hazards to organisms outside the target, and not making the target organisms drug resistant [36].

The two main bactericides commonly used in industry are formaldehyde releasers and isothiazolinone. Formaldehyde releasers could release highly volatile formaldehyde. In addition, formaldehyde changes the structure of proteins through denaturation and interacts with

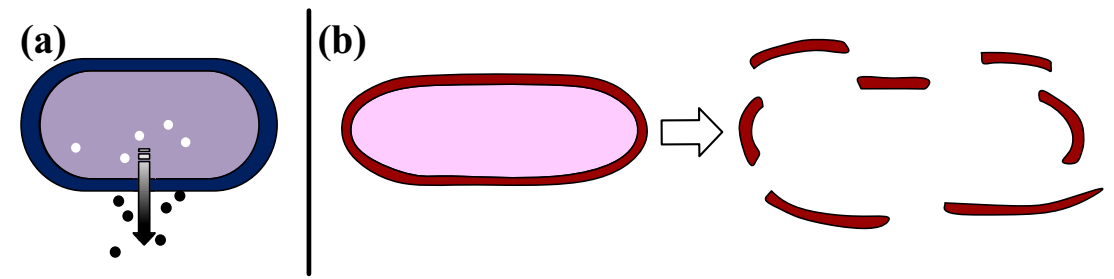

Figure 10 a Exotoxin, b Endotoxin [121] 
Table 3 Mechanism of different kinds of organic molecules to kill microorganisms [36]

\begin{tabular}{ll}
\hline Types of bactericides & Mechanism \\
\hline Acid & Interaction with cell membrane \\
Alcohol & Denature protein and dissolve cell membrane \\
Formaldehyde and formaldehyde-releasers & Combine with NH2 group and affect protein and nucleic acid \\
Biguanides & Interact with cell membrane and affect protein and nucleic acid \\
Isothiazolinone & Inhibit enzyme \\
Phenolic compounds & Denature protein and modify cell membrane \\
\hline
\end{tabular}

bacterial NAs through alkylation reactions to inhibit the excessive reproduction of bacterial and fungal populations [133], including Pseudomonas species, sulphate reducing bacteria, Fusarium species, cepacia species, and Candida species [124]. Isothiazolinone-based biological bactericides have the advantage of not relying on the mechanism of action of formaldehyde. It mainly acts on bacterial membranes and proteins [134]. It has a strong sterilization effect on sulfate-reducing bacteria and a poor inactivation effect on Pseudomonas and mycobacteria [36].

Formaldehyde releasers have a fast sterilization speed, but poor stability and strong irritation to the skin. Isothiazolinone has strong stability in cutting fluids, and it could quickly kill microorganisms. However, isothiazolinones are skin sensitizers that could cause contact dermatitis [39], and their use has been reduced [36]. Other chemical categories include phenols, pyridinone [121], iodine with propynyl carbamate, and sodium pyrithione [135].

Phenolic substances are antibacterial agents that act on cell membranes. They inactivate bacteria by interacting with the cell membrane surface to disintegrate the cell and release the substance inside the cell. Phenolics could also coagulate cell fluid, cause cell death, or inhibit cell growth [136, 137]. In addition, phenolic bactericides could inactivate acid-resistant bacteria more effectively than other bactericides. However, the chlorine contained in its component produces a special odor, and it is difficult to remove in the waste liquid [138]. Therefore, although phenolic resins have been registered for cutting fluids, they are still restricted by wastewater discharge regulations. Iodopropynylcarbamate is a broad-spectrum mold control agent with rapid bactericidal effect. However, its water solubility is poor, and its thermal stability is general. The sodium pyrithione antifungal agent has good water solubility and stability in cutting fluid, but its sterilization speed is slow [139].

\subsection{Boric Acid and Formaldehyde-Releasers}

Boric acid and formaldehyde releasers are commonly used bactericides in cutting fluids in industry. Boronic

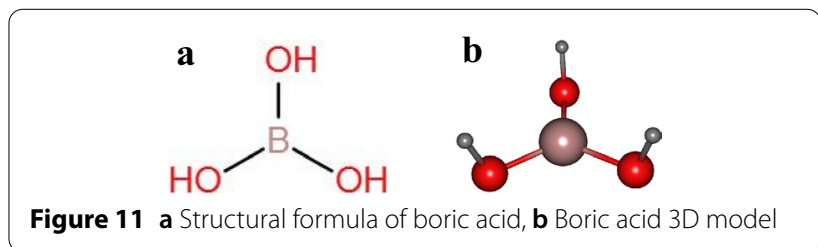

acid has a molecular formula of $\mathrm{H} 3 \mathrm{BO} 3$, and it is an inorganic acid. Its structural unit is a planar triangle [140], as shown in Figure 11. The atomic number of boron in the periodic table is 5 , and the valence electron structure is $2 \mathrm{~S} 22 \mathrm{P} 1$. Its number of valence electrons is less than the number of valence orbitals, and it has electron loss [141]. Therefore, it could easily react with the hydroxyl in organic compounds (form borate after dehydration) and form boric acid monoester, diester, triester, and tetrasubstituted spiro ring structure [140].

Formaldehyde is a colorless gas with a pungent odor. Formalin is a $37 \%-40 \%$ aqueous formaldehyde solution. Formaldehyde releasers exhibit a wide range of antibacterial activities, and they are by far the most popular and effective bactericides applied in cutting fluids. Anton C. de Groot et al. listed the CAS numbers, chemical structures, and molecular formulas of several commonly used formaldehyde releasers in water-based cutting fluids (Table 4) [142].

\subsubsection{Sterilizing Mechanisms}

Boric acid is an enzyme inhibitor that could block enzymes in phospholipid metabolism. The boron in borate is an electron-deficient element that could combine with external electrons. It could change the permeability of the cell membrane or cell wall by binding to the negatively charged cell surface, causing the cell to rupture and die.

Formaldehyde releasers control microbial reproduction by releasing formaldehyde. Their target is the amino acid or protein of bacteria. These are usually enzymes or other proteins or important components that undertake the main functions of the cell. Its release rate of formaldehyde 
Table 4 Formaldehyde-releasers [142]

\begin{tabular}{|c|c|c|c|}
\hline Name & CAS & Molecular formula & Chemical structure \\
\hline Bioban ${ }^{\circledR C S}-1135$ & $51200-87-4 ; 75673-43-7$ & $\mathrm{C}_{6} \mathrm{H}_{13} \mathrm{NO} ; \mathrm{C}_{5} \mathrm{H}_{11} \mathrm{NO}$ & \\
\hline Bioban ${ }^{\circledR C S}-1246$ & $7747-35-5$ & $\mathrm{C}_{7} \mathrm{H}_{13} \mathrm{NO}_{2}$ & \\
\hline Bioban ${ }^{\circledR} \mathrm{P}-1487$ & $37304-88-4$ & $\mathrm{C}_{13} \mathrm{H}_{25} \mathrm{~N}_{3} \mathrm{O}_{4} ; \mathrm{C}_{8} \mathrm{H}_{16} \mathrm{~N}_{2} \mathrm{O}_{3}$ & \\
\hline 1,6-Dihydroxy-2,5-dioxane & $3586-55-8$ & $\mathrm{C}_{4} \mathrm{H}_{10} \mathrm{O}_{4}$ & \\
\hline
\end{tabular}

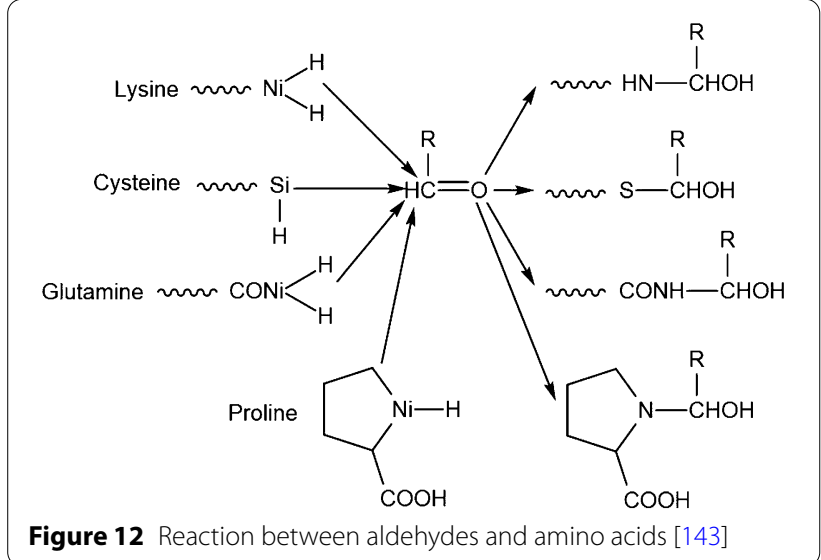

has a relationship with the properties of the bactericides, its concentration, the $\mathrm{pH}$ value of cutting fluid, temperature, and the degree of microbial contamination [132]. Aldehydes belong to the group of electrophilic addition active species. Given the lack of electrons at its carbonyl carbon atom, it could react with cell nucleophiles to exert antibacterial activity. The nucleophilic reaction with aldehydes in cells are amino and thiol groups, amino acid, or protein amide groups. These are the components of enzymes, as shown in Figure 12.

The reaction process of formaldehyde with amino group on protein is as follows [144].
In acid or neutral solutions:

$$
\mathrm{P}-\mathrm{NH}_{2}+\mathrm{CH}_{2} \mathrm{O} \rightarrow \mathrm{P}-\mathrm{NCH}_{2}+\mathrm{H}_{2} \mathrm{O} \text {. }
$$

In alkaline solution:

$$
2 \mathrm{P}-\mathrm{NH}_{2}+\mathrm{CH}_{2} \mathrm{O} \rightarrow \mathrm{P}-\mathrm{NHCH}_{2} \mathrm{NH}-\mathrm{P}+\mathrm{H}_{2} \mathrm{O} \text {. }
$$

The reaction of sulfhydryl group on protein molecule with formaldehyde is as follows:

$$
\mathrm{P}-\mathrm{SH}+\mathrm{CH}_{2} \mathrm{O} \rightarrow \mathrm{P}-\mathrm{SCH}_{2} \mathrm{OH} \text {. }
$$

\subsubsection{Bactericidal Effect}

$\mathrm{Li}$ et al. studied the germicidal efficacy of boric acid bactericides (ammonium borate) and formaldehyde releasers (triazine) with different concentrations. Before the experiment, the total number of bacterial colonies was more than $10^{7} \mathrm{CFU} / \mathrm{mL}$, and the total number of fungal colonies was more than $10^{3} \mathrm{CFU} / \mathrm{mL}$. The test results are shown in Figure 13.

The experiments showed that the antibacterial ability of ammonium borate and triazine bactericides was positively correlated with the concentration. The inactivation effect on bacteria was stronger than on fungi. The ammonium borate concentration of $5 \%$ showed enhanced sterilization performance. Triazines have a fast sterilization speed, but the inhibition time of bacteria and fungi after 


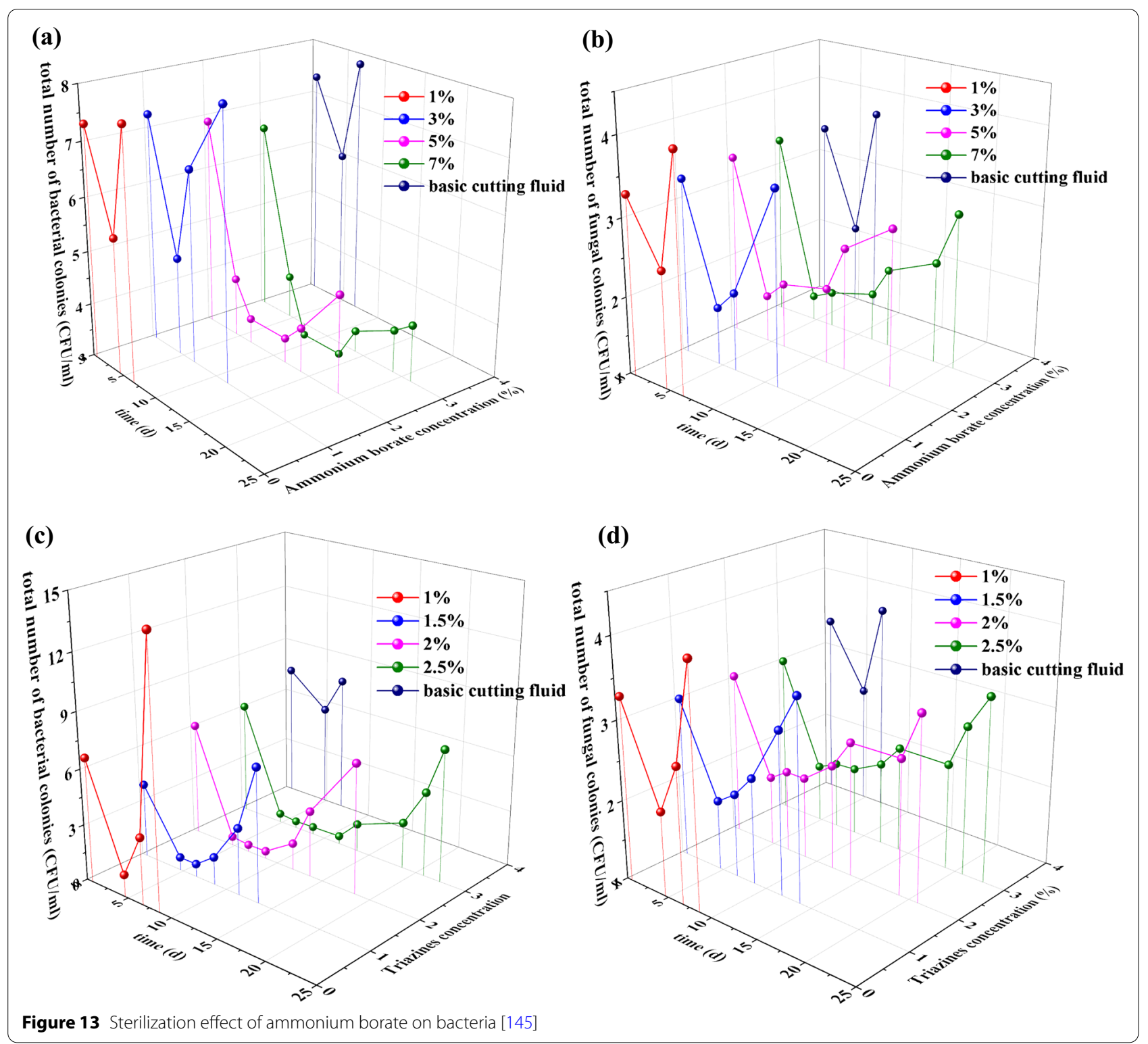

sterilization is not long enough. The number of fungal colonies quickly recovers to the initial value.

\subsubsection{Harm to the Environment and Workers}

Boron is a common element in rock, soil, and water. Inhalation of boric acid or borate could cause respiratory irritation. Researchers found that when the average intake of boric acid was $4.1 \mathrm{mg} / \mathrm{L}$, the eyes were stimulated; the mouth, nose, or throat dried; and the throat suffered from pain and coughing. [146]. In addition, boron is a dynamic trace element. It affects the metabolism or utilization of many substances involved in life, including calcium, copper, magnesium, nitrogen, glucose, triglycerides, reactive oxygen species, and estrogen.
Through these effects, boron could affect the function or composition of multiple human systems including, the immune system, blood, brain, and bones. EU regulators consider boric acid to be Class $1 \mathrm{~B}$ reproductive toxic. The World Health Organization stipulates that the maximum concentration limits of boron in industrial drainage and drinking water are 10 and $1 \mathrm{mg} / \mathrm{L}$, respectively [147].

Due to the presence of formaldehyde releasers in cutting fluid, workers who frequently touch with cutting fluid are prone to occupation dermatitis. The incidence rate of hand eczema was reported to be $20 \%-25 \%$ in 3 years. Formaldehyde is also a strong sensitizer, and it is a common cause of allergic contact dermatitis. In the United States, the sensitization frequency of this 
allergen is approximately $8 \%-9 \%$. The European plaque test results reported that the sensitization frequency is between $2 \%$ and $3 \%$, and the Spanish sensitization frequency is $1.61 \%$ [148]. Irritative contact dermatitis is more common than allergic contact dermatitis. Anton de Groot counted the sensitization rates of different kinds of formaldehyde releasers $[124,149]$.

\section{Exploration of New Bactericides}

In addition to the existing bactericides used in cutting fluids, the bactericides used in other fields were discussed to explore more possibilities for various bactericidal materials to be applied in cutting fluids, including nanomaterials and transition metal complex used in medicine, animal and plant science, and other fields.

\subsection{Nanomaterials}

Bacteria could develop resistance to bactericides by secreting enzymes that degrade the bactericides, thus altering the permeability of the cell membrane and the target proteins of the bactericides [42, 150]. Therefore, the sterilization performance of the bactericides is greatly reduced after a period of application. Other alternatives must be considered. Nanoparticles are small in size, and they could easily pass through cell membranes. Nanoparticles enter the cell faster than the cell removes the nanoparticles. Therefore, nanoparticles could accumulate in the cell, thereby hindering the physiological process of the cell and destroying the cell structure and function [151]. The use of nanomaterials could thus be considered as an alternative to bactericides. Some scholars have found that the antibacterial activity of nanomaterials is related to shape, size, electronic structure, and surface properties [42]. Bacteria could be inactivated through various mechanisms, including cell membrane rupture, inhibition of nutrients from entering the cell, and blocking of cells from attaching to solid surfaces [41, 42]. Various nanomaterials are known to produce bactericidal effects against Gram-negative and -positive bacteria, such as $\mathrm{Cu}$ [152], $\mathrm{CuO}$ [153, 154], $\mathrm{Ag}$ [152, 155], silver phosphate [156], graphene-derived materials, and carbon nanotubes [157]. The effect of nanoparticles on Gramnegative bacteria is considerably more significant than that on Gram-positive bacteria [158].

Since the ancient times, people have known that silver and its compounds have strong antibacterial and bactericidal effects. They have broad-spectrum antibacterial activity against bacteria and fungi [159-161]. Compared with other metals, silver is more toxic to microorganisms than to mammalian cells [162, 163]. Humberto H. Lara found that silver nanoparticles could inhibit the formation of biofilms by destroying the cell wall of Candida albicans. They could also disrupt the membrane potential to create small pores in the cell membrane, thereby triggering the leakage of ions and other substances in the cell to kill the bacteria. He proved their sterilization activity against Candida albicans through experiments [164]. Anna Ogar studied the inhibitory effect of silver nanoparticles on fungi. Experimental results showed that their inactivation effect on fungi depends on the concentration and release rate of $\mathrm{Ag}$ ions. The author also found that silver nanoparticles with a concentration of 30-200 $\mathrm{mg} / \mathrm{L}$ could significantly inhibit the growth of fungi [165]. Melisa Monerris explored the sterilization ability of silver ion nanocomposites against $P$. aeruginosa [166]. Nasrollahi studied the inhibitory effects of silver nanoparticles on Candida albicans and Saccharomyces cerevisiae and found through experiments that they have a strong inactivation effect. The $50 \%$ minimun inhibitory concentration values for Candida albicans and Saccharomyces cerevisiae were 0.5 and $4 \mathrm{mg} / \mathrm{mL}$, while the $90 \%$ minimun inhibitory concentration values were 2 and $32 \mathrm{mg} / \mathrm{mL}$, respectively. The reason may be that nanosilver particles could inactivate bacteria by destroying the integrity of the membrane, affecting the permeability of the membrane, and reducing the activity of enzymes [163]. In the antibacterial activity test, a certain amount of nanoparticles was added to the cutting fluid. The smaller the particle size of the nanoparticles is, the more contact area with the cutting fluid, hence the better the antibacterial performance. Vijay C Verma studied the synthesis of nanosilver and its antibacterial activity against $C$. albicans, Pseudomonas fluorescens and E. coli. Its average minimum inhibitory concentration (MIC) for C. albicans was $5.83 \mu \mathrm{g} / \mathrm{mL}$, and the minimum bactericidal concentration (MBC) was $9.7 \mu \mathrm{g} / \mathrm{mL}$ [167]. Yen San Chan studied the antibacterial properties of synthetic silver nanoparticles (AgNPs) against S. aureus, E. coli, A. niger, and C. albicans. The results showed that AgNPs have strong antibacterial and antifungal activities [168].

Suresh studied nickel oxide (n-Nio) and nickel oxide (f-Nio) nanoparticles functionalized with the surface of 5 amino-2-mercaptobenzimidazole (AMB) and the antibacterial activity of $\mathrm{Ag}_{3} \mathrm{O}_{4}$ nanoparticles and $\mathrm{AMB}$ surface functionalized $\mathrm{Ag}_{3} \mathrm{O}_{4}$ nanoparticles against P. aeruginosa, $S$. aureus, and A. niger. The experimental results showed that the antibacterial and antifungal activities of the functionalized nickel oxide nanoparticles were greater than those of the unmodified nonfunctionalized nickel oxide nanoparticles. The MIC of $\mathrm{f}-\mathrm{NiO}$ was $20 \mathrm{mg} / \mathrm{mL}$, and the $\mathrm{MIC}$ of $\mathrm{n}-\mathrm{NiO}$ was 80 $\mathrm{mg} / \mathrm{mL}$. The antibacterial and antifungal activities of non-functionalized $\mathrm{Ag}_{3} \mathrm{O}_{4}$ nanoparticles were larger than those of functionalized $\mathrm{Ag}_{3} \mathrm{O}_{4}$ nanoparticles. The stronger antibacterial effect of the functionalized nickel oxide nanoparticles may be due to the enhanced 
dispersion of the nanoparticles. The functionalized $\mathrm{Ag}_{3} \mathrm{O}_{4}$ may be due to the increase in particle size that reduces the antibacterial effect $[158,169]$.

Pooja Devi studied the synthesis of silica/silver coreshell nanoparticles and bactericidal activity against Bacillus subtilis (Gram-positive) and E. coli (Gramnegative) and found that the synthesized nanoparticles have inhibitory effects on both bacteria. The antibacterial ability of the experimental materials is related to the proportion of silver on the surface of the silicon core. When the mass fraction of silver was $0.5 \%$, the MIC was $250 \mu \mathrm{g} / \mathrm{mL}$, and when the mass fraction of silver was $15 \%$, the MIC was $7.8 \mu \mathrm{g} / \mathrm{mL}$ [170].

Graphene oxide (GO) could destroy cell membranes to kill bacteria through chemical reactions. Reduced GO (RGO) destroys cell membranes through mechanical stress to kill bacteria. Iman Sengupta investigated experimentally the effect of GO and reduced RGO on $S$. aureus and $P$. aeruginosa. The experimental results found that the inhibition rates of GO against $S$. aureus and $P$. aeruginosa were $93.7 \%$ and $48.6 \%$, respectively, while the inhibition rates of RGO were $67.7 \%$ and 93.3\%, respectively [42].

Muhammad Arshad studied the synthesis of zincdoped silica nanoparticles synthesized in three different solvents (acetonitrile, $\mathrm{n}$-hexane, and isoamyl alcohol), along with their antibacterial and antifungal properties. He mainly studied the biological activity against $B$. subtilis and E. coli and the bacteriostatic activity against Candida and A. niger [171].

Copper ions could damage cell membranes by being adsorbed to the bacterial cell surface, thus curing protein structure or altering enzyme function [172-174]. Its antibacterial mechanism is mainly attributed to the strong adsorption of copper ions by bacterial cells. This adsorption effect has a great relationship with copper ion concentration [175]. Ramesh synthesized a simple, low-cost, and environmental friendly $\mathrm{Cu}_{2} \mathrm{O}$ nanoparticle. He used E. coli as a model to study the antibacterial properties of nano $\mathrm{Cu}_{2} \mathrm{O}$ nanoparticles against Gramnegative bacteria. An antibacterial test was performed on E. coli on agar plates containing different concentrations of nanoparticles. The initial number of bacterial colonies on threagar plates was approximately $10^{6}$ $\mathrm{CFU} / \mathrm{mL}$. Figure 14 shows the variation in the number of bacterial colonies as a function of nano- $\mathrm{Cu}_{2} \mathrm{O}$ concentration. When the concentration of these particles was $10 \mu \mathrm{g} / \mathrm{mL}$, the growth of bacteria was inhibited by $65 \%$. The number of bacterial colonies grown on plates with nanoparticles exceeding $30 \mu \mathrm{g} / \mathrm{mL}$ decreased significantly, and the nanoparticle concentration of 50-60 $\mu \mathrm{g} / \mathrm{mL}$ could inhibit the growth of bacteria by $100 \%$ [176].

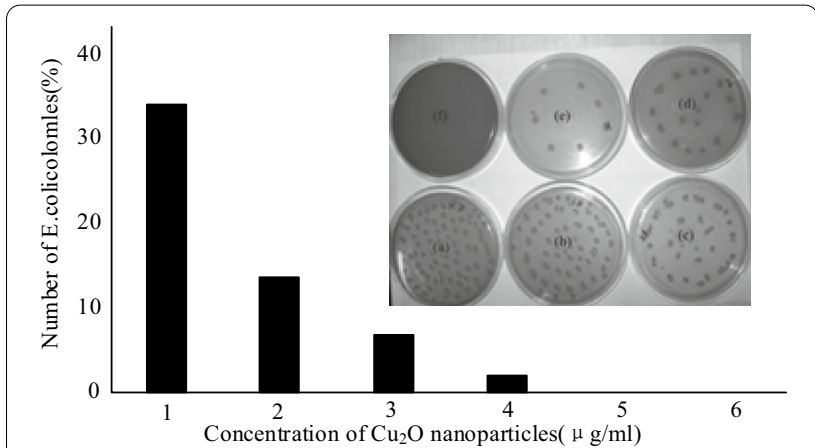

Figure 14 Relationship between the number of $\mathrm{E}$. coli colonies and the number of $\mathrm{CuO}\left(\mathrm{Cu}_{2} \mathrm{O}\right.$ nanoparticles in the $\mathrm{LB}$ agar plate are expressed as the percentage of the number of colonies grown on the control plate without $\mathrm{Cu}_{2} \mathrm{O}$ ) [176]

Table 5 summarizes the influence of different nanomaterials and their particle size on the sterilization performance.

As shown by the above studies, nanomaterials mostly achieve the inactivation of microorganisms by disturbing the potential of the cell membrane and disrupting the cell membrane. As Gram-positive bacteria are structurally different from Gram-negative bacteria, their multiple peptidoglycan layers could reinforce the stability of the cell membrane. Thus, the effect of nanomaterials on the action of Gram-negative bacteria should be higher than that on Gram-positive bacteria. In addition, the smaller the particle size of nanoparticles is, the more favorable it is to pass through the cell membrane, combining with other substances inside the cell. Therefore, a stronger bactericidal capacity could also be expected.

\subsection{Transition Metal Complex}

Metals are good conductors of electricity and heat, and they could form ionic and ionic bonds with nonmetals. Atoms in metals could easily lose electrons to form cations surrounded by free electrons. Thus producing conductive and antibacterial effects [177]. Heavy metals could be toxic to bacteria. This toxicity may be due to their chemical affinity with macromolecular thiol groups $[44,45]$. Several modes of action of heavy metals are shown in Figure 15 [178].

The complexation of bactericides with transition metals could improve the biological activity of the original bactericides. Jie Li synthesized two $\mathrm{Cu}$ (II) complexes $\left[\mathrm{CuL}_{2}{ }_{2}(\mathrm{OAc})_{2}\right] \cdot \mathrm{MeOH}(1)$ and $\left[\mathrm{CuL}_{2}^{2}(\mathrm{OAc})_{2}\right]$ by using commercial bactericides paclobutrazol $\left(\mathrm{L}^{1}\right)$ and diconazole $\left(\mathrm{L}^{2}\right)$ as ligands (2). Ligand $\mathrm{L}^{2}$ has $\mathrm{C}=\mathrm{C}$ bond and 2,4-dichlorophenyl group, and it has a higher level of synergy. Therefore, complex 2 has stronger antifungal activity. Experimental studies on the synergy 
Table 5 Nano material sterilization performance

\begin{tabular}{|c|c|c|c|c|c|}
\hline Material & Size $(\mathrm{nm})$ & $\mathrm{MIC}(\mathrm{mg} / \mathrm{mL})$ & Zone of inhibition (mm) & Percentage inhibition & Ref. No. \\
\hline \multirow[t]{5}{*}{ AgNPS } & & & $8.1-36.4$ & & [166] \\
\hline & $50-80$ & $0.3 \times 10^{-4}-0.047$ & $\begin{array}{l}\text { S. aureus: } 1.4-2.0 ; \\
\text { E. coli: } 0.8-1.8\end{array}$ & & [168] \\
\hline & & & $9-16$ & & \\
\hline & & $\begin{array}{l}\text { C.albicans: } \\
\text { MIC } 50=0.5 \\
\text { MIC90 }=2 ; \\
\text { S. cerevisiae: } \text { MIC } 50=4 \text {, } \\
\text { MIC } 90=32\end{array}$ & & & [163] \\
\hline & $10-25$ & $5.8 \times 10^{-3}$ & & & [167] \\
\hline $\mathrm{n}-\mathrm{Ag}_{3} \mathrm{O}_{4}$ & 18 & & $\begin{array}{l}\text { S. aureus: 13-16; } \\
\text { P. Aeruginosa: 13-16 }\end{array}$ & & [169] \\
\hline $\mathrm{f}-\mathrm{Ag}_{3} \mathrm{O}_{4}$ & 30 & & $\begin{array}{l}\text { S. aureus: 7-8; } \\
\text { P. Aeruginosa: 7-11 }\end{array}$ & & \\
\hline $\mathrm{n}-\mathrm{NiO}$ & 16 & & $\begin{array}{l}\text { S. aureus: 5-6; } \\
\text { P. Aeruginosa: 6-7 }\end{array}$ & & [158] \\
\hline $\mathrm{f}-\mathrm{NiO}$ & 20 & & $\begin{array}{l}\text { S. aureus: } 7-15 ; \\
\text { P. Aeruginosa: } 12-17\end{array}$ & & \\
\hline $\mathrm{Cu}_{2} \mathrm{O}$ & & $\begin{array}{l}\mathrm{MIC} 50=0.01 \\
\mathrm{MIC} 90=0.055\end{array}$ & & & [176] \\
\hline $\mathrm{SiO}_{2}$ & $50-100$ & $\begin{array}{l}\text { B. subtilis: } 6 \%-2 \% \text {; } \\
\text { E. coli: } 4.5 \%-1 \%\end{array}$ & & & [171] \\
\hline $\mathrm{SiO}_{2}+\mathrm{Ag}$ & $16-35$ & $\begin{array}{l}\text { B. subtilis: } 0.016-0.500 \text {; } \\
\text { E. coli: } 0.008-0.25\end{array}$ & & & [170] \\
\hline $\mathrm{GO}$ & & & & $\begin{array}{l}\text { S. aureus: } 97.3 \% \\
\text { P. Aeruginosa: } 48.6 \%\end{array}$ & {$[42]$} \\
\hline $\mathrm{rGO}$ & & & & $\begin{array}{l}\text { S. aureus: } 67.7 \% \\
\text { P. Aeruginosa: } 93.3 \%\end{array}$ & \\
\hline
\end{tabular}

Note: Staphylococcus aureus: S. aureus; Pseudomonas aeruginosa: P. Aeruginosa; Escherichia coli: E. coli; Bacillus subtilis: B. subtilis; candida albicans: C.albicans; Saccharomyces cerevisiae: S. cerevisiae; non-functionalized silver oxide nanoparticles referred as n-Ag3O4, functionalized nanoparticles as f-Ag3O4; nonfunctionalized nickel oxide nano-particles are referred to as $\mathrm{n}-\mathrm{NiO}$, functionalized nickel oxide nanoparticles as $\mathrm{f}-\mathrm{NiO}$; graphene oxide: $\mathrm{GO}$; reduced $\mathrm{GO}$ : $\mathrm{rGO}$

between $\mathrm{Cu}^{2+}$ and ligands and theoretical studies on the electronic structure of the complexes showed that the increase in active sites for copper ion, the synergy between copper ion and ligands, and the enhanced permeability through microbial cell membranes all contribute to the enhanced bactericidal performance [179].

VM Farzaliyev studied Schiff bases and their complexes with transition metals $\left(\mathrm{Cu}^{2+}, \mathrm{Ni}^{2+}\right.$, and $\left.\mathrm{Co}^{2+}\right)$ against lactic acid bacteria, $P$. aeruginosa, A. niger, Cladosporium resinosum, Penicillium, S. globosa, and Trichoderma viride. The antibacterial performance and synthesis scheme is shown in Figure 16. The experimental results showed that the antibacterial properties of Schiff bases and their metal complexes reached the level of the selected standard bactericides, and in some cases, even exceeded the standard bactericides. In addition, due to the presence of additional dimethylamine fragments in the molecule, 4-dimethylamino-1 benzylaniline and its complexes with $\mathrm{Cu}^{2+}, \mathrm{Ni}^{2+}$, and $\mathrm{Co}^{2+}$ demonstrated low concentrations $(0.25 \%-0.5 \%)$, sterilization, and bactericidal properties [180].
Fatullayeva synthesized bis-(3,5-di-tert-butyl-salicylic acid) hydrazone and its analogues of dihydrazine succinate. He obtained the complexes of $\mathrm{Mn}$ (II) and Fe (II) with these ligands and found through tests that the obtained compounds have high bactericidal and bactericidal activities [181]. Rahimova synthesized the complexes of $\mathrm{Cu}$ (II) and $\mathrm{Ni}$ (II) with N,N-bis (p-dimethylaminobenzyl) diaminopropane, analyzed their antibacterial properties. and found that the synthesized compounds had strong bactericidal and bactericidal activities [182].

Under the chelation of transition metal and ligand, the polarity of the metal ion is greatly reduced due to the overlap of the ligand orbital and the partial participation of the positive charge of the metal ion and the donor base [183]. In addition, the compounding process could increase the lipophilicity of the central metal atom, beneficial for the complex to penetrate the lipid layer of the microbial cell membrane [184]. Table 6 summarizes the bactericidal properties of some transition metal complexes in the existing literature. A rule could be drawn 

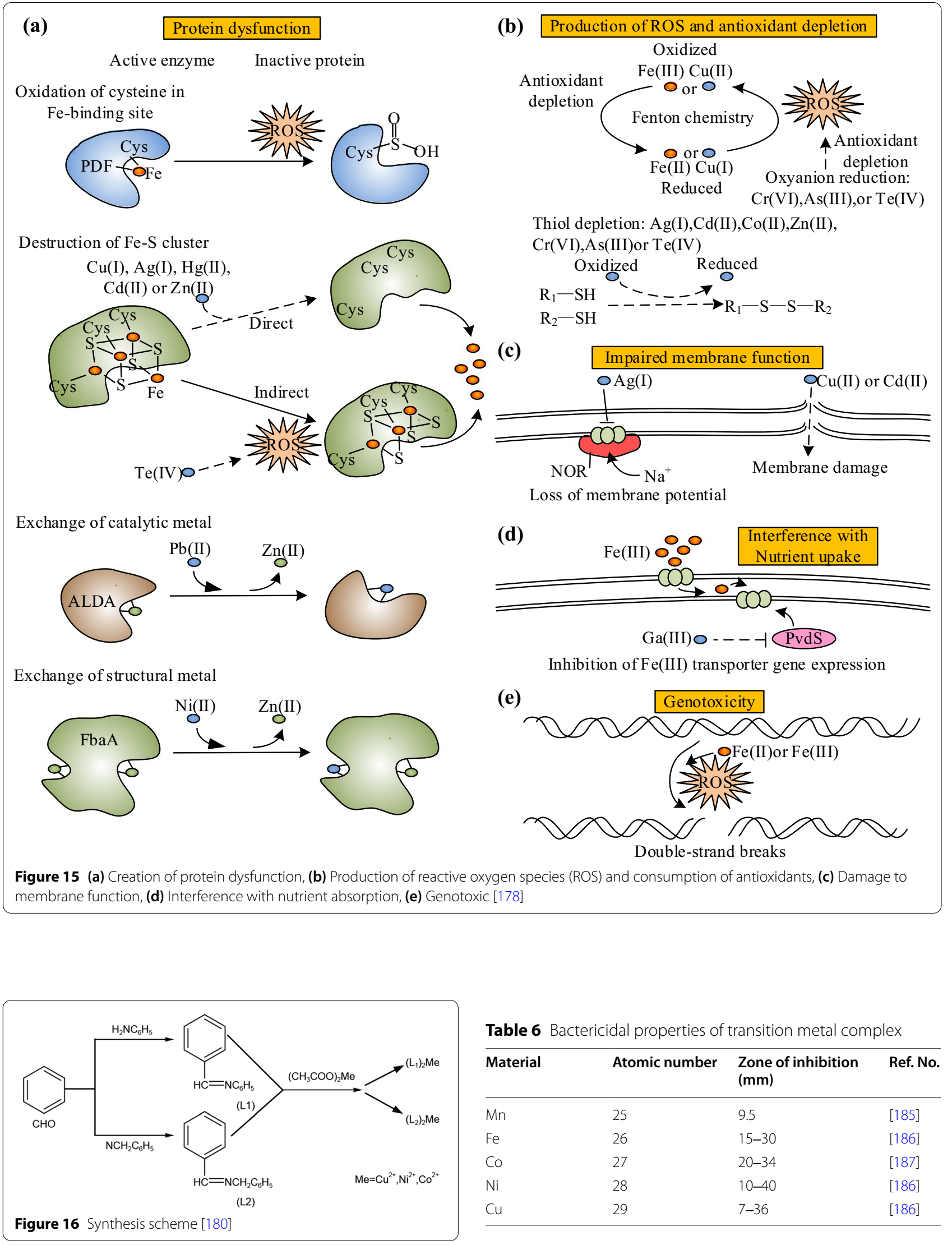

Table 6 Bactericidal properties of transition metal complex

\begin{tabular}{llll}
\hline Material & Atomic number & $\begin{array}{l}\text { Zone of inhibition } \\
(\mathbf{m m})\end{array}$ & Ref. No. \\
\hline $\mathrm{Mn}$ & 25 & 9.5 & {$[185]$} \\
$\mathrm{Fe}$ & 26 & $15-30$ & {$[186]$} \\
$\mathrm{Co}$ & 27 & $20-34$ & {$[187]$} \\
$\mathrm{Ni}$ & 28 & $10-40$ & {$[186]$} \\
$\mathrm{Cu}$ & 29 & $7-36$ & {$[186]$} \\
\hline
\end{tabular}


from Table 6 as follows: as the atomic number of transition metals increases, the sterilization performance of the complexes improves to a certain extent.

Scholars found that the products after complexation of transition metals and bactericides could prolong the use time of bactericides and enhance the energy efficiency of sterilization. Furthermore, a large number of chips could be generated during metal processing, and the metal ions precipitated during the processing may enhance the sterilization ability of the complex.

\subsection{Physical Sterilization Method}

In addition to the study of new chemical bactericides, physical methods could be used to inactivate microorganisms in cutting fluid. Ozone, UV, and others have certain bactericidal effect in various fields.

\subsubsection{Ultraviolet Ray}

The wavelength of UV light is $10-400 \mathrm{~nm}$, and its radiation could cause the connection between adjacent pyrimidine bases in DNA. This phenomenon inhibits its correct replication during cell division and affect the reproduction of microorganisms. As a rule of thumb, the mechanisms through which UV radiation could damage microorganisms are as follows: (i) the photo-induced reactions resulting from the direct absorption of UV photons by biopolymers, especially NAs and proteins, which are the basic constituents in common between bacteria and viruses [188, 189], and (ii) the photo-oxidation triggered by ROS generated after UV irradiation of exogenous and endogenous photosensitizers, i.e., powerful oxidant materials or photosensitive molecules other than NAs and proteins [190].

In addition, UV rays are almost non-hazardous, and they do not cause fire or toxic contact with workers; the effect of UV sterilization depends on the radiation power, radiation time and radiation area. Due to the low transparency of the cutting fluid, the penetration depth of UV rays is reduced, and the sterilization effect is greatly reduced. Microbes have the ability to repair themselves, which could repair the damage caused by radiation, further reducing the sterilization ability of UV light. Ensuring a higher power when the cutting fluid is sterilized by UV rays is necessary and the cutting fluid should be kept flowing continuously to achieve enhanced sterilization effect [191].

A notable detail that the inactivation of microorganisms is strictly dependent on the amount of radiation absorbed and capable of giving rise to detrimental effects. Accordingly, some parameters play a key role on the disinfection behavior, one above all is UV dose (referred to as fluence), generally expressed as the product of the UV light intensity (I) and the irradiation time (Tirr), where
UV dose is commonly expressed in $\mathrm{J} / \mathrm{cm}^{-2}=\mathrm{W} \cdot \mathrm{s} / \mathrm{cm}^{-2}$ [192].

Souza used 16 caluv lamps for $24 \mathrm{~h}$ of treatment of cutting fluid and achieved an average reduction of $99.70 \%$ contamination of synthetic cutting fluid [193]. In addition, considering that the opacity of the cutting fluid weakens the transmission of UV light to a certain extent, Johnson et al. used a high-output UV lamp that could withstand harsh chemical environments for experiments. Enhanced results were achieved, and the UV bactericidal rate reached more than 99\% [47]. Weigel's UV sterilization experiment found that $E$. coli cells were inactivated within 5-15 s, and fecal E. coli cells were inactivated within $30 \mathrm{~s}$ [194].

\subsubsection{Ozone}

Ozone is one of the most effective strong oxidants that could effectively inactivate microorganisms. In addition, it could rapidly decompose into oxygen molecules in water, and it does not form any secondary pollutants. Kristina et al. verified the sterilization ability of ozone through experiments. The initial bacterial concentration was $10^{7} \mathrm{CFU} / \mathrm{mL}$, and the microorganisms were completely eliminated $20 \mathrm{~min}$ later $[48,49]$. Ma proposed an ozone treatment system using air DBD plasma to stably generate high concentration ozone and inject waterbased cutting fluids. He used Klebsiella pneumoniae, $P$. aeruginosa, E. coli, and $P$. vulgaris for sterilization experiments and counted the microbial colonies in the treated water for 3 days, as shown in Figure 17. Experiments confirmed that the sterilization rate of water-based cutting fluids could reach $99.99 \%$. The turbidity, $\mathrm{pH}$ value, and odor of water-based cutting fluids all improved. Among them, K. pneumoniae proliferated slightly after 2 days of sterilization, and $P$. aeruginosa proliferated slightly after 3 days of sterilization. Therefore, to maintain the effect of ozone treatment, Sukhwal Ma proposed a strategy of using an air DBD system to treat the cutting fluid every 3 days [122].

The vertical axis in Figure 17 is the logarithmic value of $\mathrm{N} / \mathrm{N}_{0}$, where $\mathrm{N}_{0}$ is the number of surviving control colonies in CFU $/ \mathrm{mL}$. The average control numbers were $8.2 \times 10^{6}, 7.0 \times 10^{6}, 2.4 \times 10^{6}$, and $2.8 \times 10^{6} \mathrm{CFU} / \mathrm{mL}$; the results showed that the values of $\log \left(\mathrm{N} / \mathrm{N}_{0}\right)$ were -6 , $-5.6,-5.9$, and -6.15 , respectively. This logarithmic scale indicated that more than $99.9 \%$ of bacteria were killed [122].

Nadine Madanchi developed an experimental cutting fluid circulation system and studied the inactivation effect of ozone, UV, and other sterilization methods on microorganisms in the cutting fluid under this system. The experimental results are shown in Figure 18 [191]. Both methods of sterilization were found to 

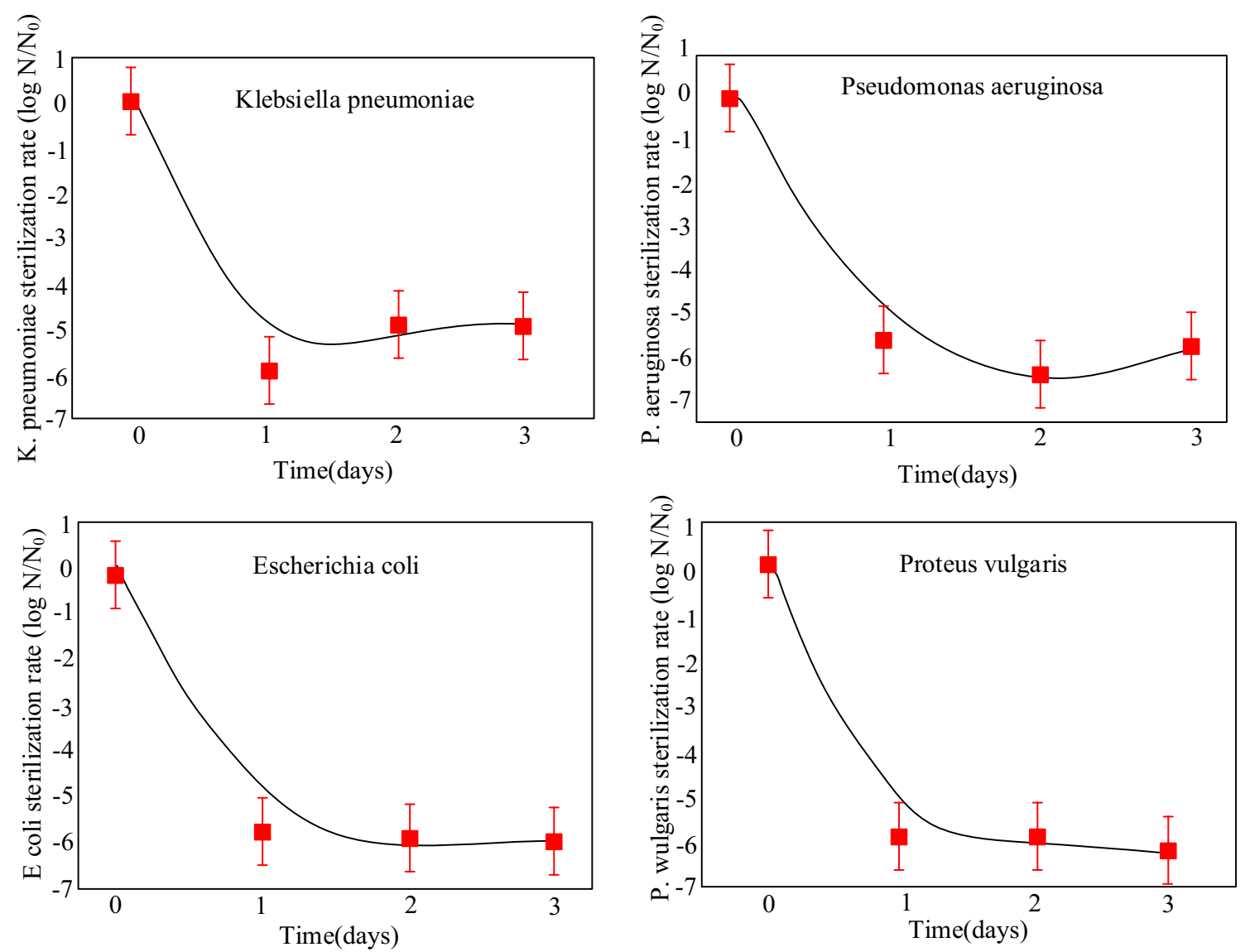

Figure 17 Disinfection curve of Klebsiella pneumoniae, Pseudomonas aeruginosa, Escherichia coli, and Pseudomonas vulgaris in DBD plasma of ozone-treated air [122]
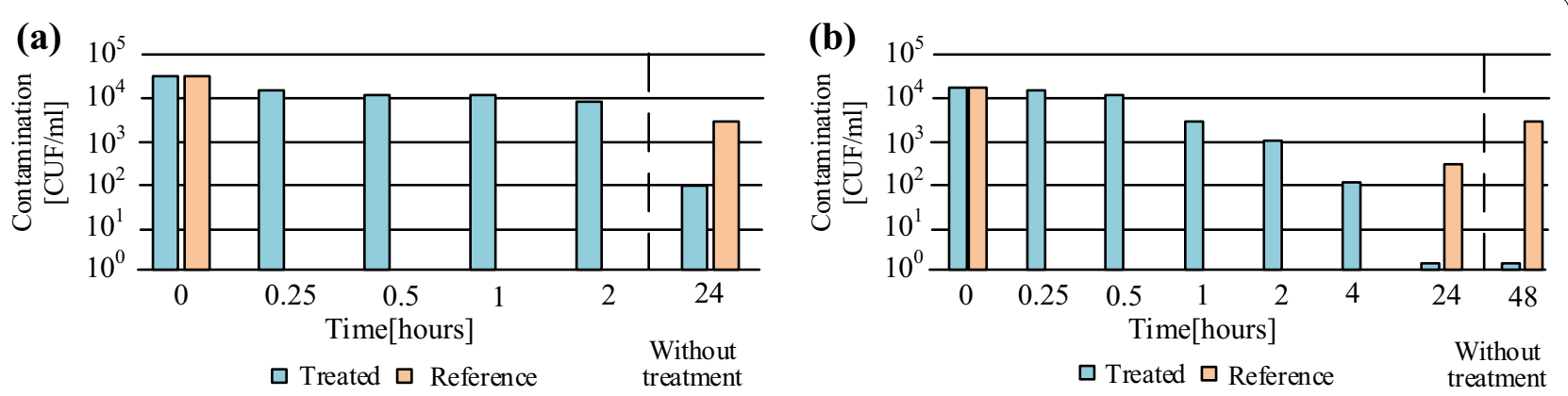

Figure 18 (a) Influence of ozone on the bacteria in the cutting fluid, (b) Influence of ultraviolet rays on the bacteria in the cutting fluid [191]

have enhanced results. The effect of ozone on cutting fluid was not obvious within $2 \mathrm{~h}$, but the microorganism decreased from $10^{4.5} \mathrm{CFU} / \mathrm{mL}$ to $10^{2} \mathrm{CFU} / \mathrm{mL}$ after $24 \mathrm{~h}$. Within $24 \mathrm{~h}$, the sterilization effect of UV was remarkable, and almost no bacteria could be detected.
In addition, the experimental results demonstrated that the number of microorganisms in the cutting fluid without sterilization treatment was reduced to a certain extent. Therefore, the flow of cutting fluid also helps reduce the microbial population [191]. 


\subsubsection{Fine Bubbles}

Fine bubbles (defined as bubbles with a diameter below $100 \mu \mathrm{m}$, referred to as FB) could fulfill different functions depending on their gas composition, bubble size, and bubble density, such as the action of microbubble disruption for bactericidal and cleaning [195]. Bubbles with a diameter of $1-100 \mu \mathrm{m}$ are called microbubbles (MBs), and bubbles with a diameter of less than $1 \mu \mathrm{m}$ are called ultrafine bubbles (UFBs). Because UFB is small in size, it could stay in the liquid for a longer time, thus takes longer to function. Hiroko Yamada prepared UFBs with two gases (air and $\mathrm{CO}_{2}$ ), and the bactericidal effect against $P$. aeruginosa (gram-negative bacteria) and $S$. aureus (gram-positive bacteria) was experimentally verified [50]. The experimental results found that the sterilization rate of $\mathrm{CO}_{2}$-UFB was $100 \%$ against $P$ aeruginosa and $0 \%$ against $S$. aureus. Fluorescence microscopic observation showed that the cause of $P$. aeruginosa cell death was cell wall damage, because the cell wall thickness was 6-10 nm for $P$. aeruginosa and 20-40 $\mathrm{nm}$ for $S$. aureus. In addition, the cell wall of Gram-positive bacteria is composed of multiple peptidoglycan layers. These peptidoglycan layers could reduce the internal pressure of bacteria and prevent cell rupture [50].

Table 7 summarizes the sterilization effects of different sterilization methods. Ozone and UV rays have better sterilization effects, while FB sterilization could only act on Gram-negative bacteria.

\section{Comprehensive Evaluation of Sterilization Methods}

On the basis of the above research status, a comprehensive comparative evaluation of traditional sterilization methods and physical sterilization, as well as nanomaterials and transition metal complexes was conducted in this paper. The evaluation indicators included sterilization performance, hazard, degradability, and economy, as shown in Table 8.

Different modes of sterilization were found to have their own advantages and disadvantages through the above multiple modes of sterilization. The sterilizing activity of each methods on different microorganisms

Table 7 Sterilization effect of physical sterilization methods

\begin{tabular}{|c|c|c|c|}
\hline Method & $\mathrm{MIC}(\mathrm{mg} / \mathrm{mL})$ & $\begin{array}{l}\text { Colonies } \\
\text { number (CFU/ } \\
\text { mL) }\end{array}$ & Percentage inhibition \\
\hline $\mathrm{O}_{3}$ & $\begin{array}{l}\text { S. aureus: } 0.24 \\
\text { E. coli1: } 90\end{array}$ & $10^{4.5}$ to $10^{2}$ & $99.9 \%$ \\
\hline UV & & $10^{6.5}$ to 0 & $99.2 \%$ \\
\hline Fine bubble & & & $\begin{array}{l}\text { P. Aeruginosa: 100\% } \\
\text { S. aureus: 0\% }\end{array}$ \\
\hline
\end{tabular}

Table 8 Comparison of various sterilization methods

\begin{tabular}{lllll}
\hline Method & Performance & Harmfulness & Degradability & Economy \\
\hline Traditional & $* * *$ & $* * *$ & $*$ & $* *$ \\
Ozone & $* * *$ & $*$ & $* * *$ & $*$ \\
UV & $* * *$ & $*$ & $* * *$ & $*$ \\
Fine bub- & $* *$ & $*$ & $* * *$ & $*$ \\
bles & & & & \\
Nanoma- & $* *$ & $*$ & $* *$ & $* *$ \\
terials & & & & $* * *$ \\
Metal & $* * *$ & $*$ & $* *$ & \\
complex & & & &
\end{tabular}

Note: * Representative grade

also varies. For example, certain microorganisms could develop resistance to partial chemical bactericides and FB bactericidal method is more applicable to Gramnegative bacteria. Therefore, when a sterilization method could not achieve the expected effect, coupling multiple sterilization methods could be considered while ensuring the cost to extend the service life of cutting fluids.

\section{Conclusions and Outlook}

In this article, the biological stability of water-based cutting fluids and the sterilization principles and sterilization effects of various sterilization methods were reviewed. The main conclusions drawn are as follows.

(1) The molecular structure in the water-soluble cutting fluid is easily decomposed by the invading microorganisms, leading to failure, a reduction in the life of the cutting fluid, and an increase in processing costs. Especially after the microorganisms gather to form a biofilm, the covered area could promote electrochemical conditions to form an electric current, which could corrode the metal and destroy the processing quality. Therefore, improving the biological stability of water-soluble cutting fluids is very important.

(2) Traditional bactericides include borate and formaldehyde. Borate is used to change the permeability of the cell membrane to cause the bacteria to rupture and die. Formaldehyde mainly uses denaturation to change the protein structure and interact with NAs to inhibit bacterial reproduction. The main influencing factor of these two bactericidal effects is the concentration of the bactericide. When the concentration is $5 \%$, it has a better antibacterial effect. However, these two substances are extremely harmful to human health.

(3) Nanomaterials are a new type of sterilization method that has the characteristics of low toxicity 
to the human body and strong sterilization performance. They have a strong application prospect. They could disturb the cell membrane potential and affect the integrity and permeability of the cell membrane, thereby triggering the leakage of intracellular material. The smaller particle size of the nano-bactericidal materials has stronger dispersibility, which could effectively improve the sterilization performance.

(4) Transition metals have good biocompatibility, and they are easily degraded. The metal atoms in the center of the coordination compound have strong lipophilicity, which is conducive to allowing the complex to pass through the lipid layer of the microbial cell membrane. Then, it interferes with the genetic material in the nucleus. The higher the atomic number of the transition metal complexes is, the stronger the antibacterial properties. Meanwhile, the combination of the transition metal with the higher atomic number and the bactericidal compound could enhance the bacteriostatic ability of the compound. However, the underlying mechanism needs to be further explored.

(5) Physical sterilization methods, such as ozone, UV rays, and FBs have the least harm to the human body; they could kill bacteria through their strong oxidizing properties, inhibition of DNA replication, and surface tension, respectively. The sterilization effect of this kind of sterilization method is better, but the economy is not high. Whether this kind of method could be applied to industrial production depends on the research of new low-cost realization methods.

In future research, preventing the proliferation of microorganisms in cutting fluid could also be considered from the following points.

(1) Change the composition of additives in the cutting fluid. Most additives with emulsification, corrosion inhibition, and lubrication functions are straightchain organic derivatives, which are easily decomposed by microorganisms. Branched alternatives, such as isostearic acid and polyester emulsifiers, could also be considered.

(2) Develop a hybrid sterilization system to control the number of microorganisms and increase the killing rate of bacteria and the destruction rate of biofilm by using the method of combining biological sterilant and physical sterilization to extend the service life of cutting fluid.

(3) Conduct frequent liquid monitoring to measure bacteria/fungus, free oil, $\mathrm{pH}$, and concentration.
Establish and improve the database, respond to the monitoring data in a timely manner, and supplement the bactericide.

\section{Acknowledgements}

Not applicable.

\section{Authors' contributions}

$\mathrm{CL}$ was in charge of the whole trial; $\mathrm{LT}$ and $\mathrm{YZ}$ wrote the manuscript. All authors read and approved the final manuscript.

\section{Funding}

Supported by National Key Research and Development Program of China (Grant No. 2020YFB2010500), National Natural Science Foundation of China (Grant Nos. 51975305, 51905289), Shandong Provincial Major Science and Technology Innovation Engineering Projects of China (Grant No. 2019JZZY020111), Shandong Provincial Natural Science Foundation of China (Grant Nos. ZR2020KE027, ZR2020ME158, ZR2019PEE008), and Applied Basic Research Youth Project of Qingdao Science and Technology Plan (Grant No. 19-6-2-63-cg).

\section{Competing interests}

The authors declare no competing financial interests.

\section{Author Details}

${ }^{1}$ School of Mechanical and Automotive Engineering, Qingdao University of Technology, Qingdao 266520, China. ${ }^{2}$ Hanergy (Qingdao) Lubrication Technology Co., Ltd., Qingdao 266200, China. ${ }^{3}$ Nanjing Kerun Lubricants Co., Ltd., Nanjing 211106, China. ${ }^{4}$ Chengdu Tool Research Institute Co., Ltd, Chengdu 610500, China. ${ }^{5}$ School of Mechanical Engineering, Chongqing University, Chongqing 400044, China. ${ }^{6}$ Sichuan Future Aerospace Industry LLC, Shifang 618400, China. ${ }^{7}$ Shanghai Jinzhao Energy Saving Technology Co., Ltd., Shanghai 200436, China. ${ }^{8}$ Department of Sustainable and Renewable Energy Engineering, University of Sharjah, 27272 Sharjah, United Arab Emirates.

${ }^{9}$ Mechanical Engineering Department, Curtin University, 98009 Miri, Malaysia.

${ }^{10}$ College of Mechanical and Electrical Engineering, Nanjing University of Aeronautics and Astronautics, Nanjing 210016, China. ${ }^{11}$ Mechanical Engineering Department, King Fahd University of Petroleum and Minerals, Dhahran 31261, Saudi Arabia. ${ }^{12}$ Department of Mechanical Engineering, IK Gujral Punjab Technical University, Kapurthala 144603, Punjab, India.

Received: 11 June 2021 Revised: 30 October 2021 Accepted: 8 December 2021

Published online: 09 January 2022

\section{Reference}

[1] KC Wickramasinghe, H Sasahara, E A Rahim, et al. Green metalworking fluid for the sustainable machining application - A review. J. Clean Prod. 2020, 257: 120552. https://doi.org/10.1016/j.jclepro.2020.120552

[2] T Gao, C H Li, Y B Zhang, et al. Dispersing mechanism and tribological performance of vegetable oil-based CNT nanofluids with different surfactants. Tribol. Int., 2019, 131: 51-63. https://doi.org/10.1016/j.tribo int.2018.10.025

[3] M Yang, C H Li, Y B Zhang, et al. Effect of friction coefficient on chip thickness models in ductile-regime grinding of zirconia ceramics. Int. J. Adv. Manuf. Tech., 2019, 102 (5-8): 2617-2632. https://doi.org/10.1007/ s00170-019-03367-0.

[4] S Xiu, C Sun, J Duan, et al. Study on the surface topography in consideration of the dynamic grinding hardening process. Int. J. Adv. Manuf. Tech., 2019, 100(1): 209-223. https://doi.org/10.1007/ s00170-018-2744-9.

[5] M Yang, C H Li, Y B Zhang, et al. Research on microscale skull grinding temperature field under different cooling conditions. Appl. Therm. Eng., 2017, 126: 525-537. https://doi.org/10.1016/j.applthermaleng.2017.07. 183. 
[6] D Yansheng, S Xiu, X Shi, et al. Study on the effect mechanisms of pre-stress on residual stress and surface roughness in PSHG. Int. J. Adv. Manuf. Tech., 2017, 88: https://doi.org/10.1007/s00170-016-9033-2.

[7] X Cui, C Li, W Ding, et al. Minimum quantity lubrication machining of aeronautical materials using carbon group nanolubricant: From mechanisms to application. Chinese J. Aeronaut, 2021: https://doi.org/ 10.1016/j.cja.2021.08.011.

[8] C Sun, S Xiu, Y Hong, et al. Prediction on residual stress with mechanical-thermal and transformation coupled in DGH. Int. J. Mech. Sci., 2020, 179: 105629. https://doi.org/10.1016/j.ijmecsci.2020.105629.

[9] Z J Duan, C H Li, Y B Zhang, et al. Milling surface roughness for 7050 aluminum alloy cavity influenced by nozzle position of nanofluid minimum quantity lubrication. Chinese J. Aeronaut, 2021, 34 (6): 33-53. https://doi.org/10.1016/j.cja.2020.04.029.

[10] W Feng, Y Yin, M D L Mendoza, et al. Freeze-thaw method for oil recovery from waste cutting fluid without chemical additions. J. Clean Prod., 2017, 148(APR.1): 84-89. https://doi.org/10.1016/j.jclepro.2017.01.156.

[11] S Debnath, M M Reddy, Q S Yi. Environmental friendly cutting fluids and cooling techniques in machining: A review. J. Clean Prod., 2014, 83: 33-47. https://doi.org/10.1016/j.jclepro.2014.07.071

[12] E Nisbet, N Sleep. The habitat and nature of early life. Nature, 2001, 409(6823): 1083-1091. https://doi.org/10.1038/35059210.

[13] B T Huang, C H Li, Y B Zhang, et al. Advances in fabrication of ceramic corundum abrasives based on sol-gel process. Chinese J. Aeronaut, 2021, 34(6): 1-17. https://doi.org/10.1016/j.cja.2020.07.004.

[14] A G Huesmann-Cordes, D Meyer, E Brinksmeier, et al. Influence of additives in metalworking fluids on the wear resistance of steels. Procedia CIRP, 2014, 13(1): 108-113. https://doi.org/10.1016/j.procir.2014.04.019.

[15] B S Kumar, G Padmanabhan, P V Krishna. Performance assessment of vegetable oil based cutting fluids with extreme pressure additive in machining. J. Adv. Res. Mater. Sci., 2016, 19(1): 1-13. http://hdl.handle. net/10603/224117.

[16] KN Timmis. Handbook of hydrocarbon and lipid microbiology. Springer Berlin, 2010

[17] B K Li, CW Dai, W F Ding, et al. Prediction on grinding force during grinding powder metallurgy nickel-based superalloy FGH96 with electroplated CBN abrasive wheel. Chinese J. Aeronaut, 2020, 34(8): 65-74. https://doi.org/10.1016/j.cja.2020.05.002.

[18] Q Miao, W F Ding, W J Kuang, et al. Grinding force and surface quality in creep feed profile grinding of turbine blade root of nickel-based superalloy with microcrystalline alumina abrasive wheels. Chinese J. Aeronaut, 2021, 34(2): 576-585. https://doi.org/10.1016/j.cja.2019.11. 0061000-9361.

[19] Z J Duan, C H Li, W F Ding, et al. Milling force model for aviation aluminum alloy: Academic insight and perspective analysis. Chin. J. Mech Eng., 2021, 34:18, https://doi.org/10.1186/s10033-021-00536-9.

[20] R Kapoor, S B Selvaraju, J S Yadav. Extended tracking of the microbial community structure and dynamics in an industrial synthetic metalworking fluid system. FEMS Microbiol Ecol., 2014, 87(3): 664-677. https:// doi.org/10.1111/1574-6941.12254.

[21] M Z Liu, C H Li, C M Cao, et al. Walnut fruit processing equipment: Academic insights and perspectives. Food Eng. Rev., 2021: https://doi. org/10.1007/s12393-020-09273-6.

[22] XXXi, W F Ding, Z XWu, et al. Performance evaluation of creep feed grinding of gamma-TiAl intermetallics with electroplated diamond wheels. Chinese J. Aeronaut, 2021, 34(6): 100-109. https://doi.org/10. 1016/j.cja.2020.04.031.

[23] Y Zhang, H Li, C Li, et al. Nano-enhanced biolubricant in sustainable manufacturing: From process ability to mechanisms. Friction, 2021, 1(1): https://doi.org/10.1007/s40544-021-0536-y.

[24] M Liu, C Li, Y Zhang, et al. Cryogenic minimum quantity lubrication machining: From mechanism to application. Front. Mech. Eng., 2021: https://doi.org/10.1007/s11465-021-0654-2.

[25] H-C Flemming, S Wuertz. Bacteria and archaea on Earth and their abundance in biofilms. Nat. Rev. Microbiol., 2019, 14(7): 247-260. https:// doi.org/10.1038/s41579-019-0158-9.

[26] D Claessen, D E Rozen, O P Kuipers, et al. Bacterial solutions to multicellularity: a tale of biofilms, filaments and fruiting bodies. Nat. Rev. Microbiol., 2014, 12(2): 115-124. https://doi.org/10.1038/nrmicro3178.
[27] H-C Flemming, J Wingender, U Szewzyk, et al. Biofilms: an emergent form of bacterial life. Nat. Rev. Microbiol., 2016, 14(9): 563-575. https:// doi.org/10.1038/nrmicro.2016.94.

[28] A E Myhre, A O Aasen, C Thiemermann, et al. Peptidoglycan-an endotoxin in its own right? Shock, 2006, 25(3): 227-235. https://doi.org/10. 1097/01.shk.0000191378.55274.37.

[29] G H Mahabeleshwar, M A Qureshi, Y Takami, et al. A myeloid hypoxiainducible factor 1a-Krüppel-like factor 2 pathway regulates gram-positive endotoxin-mediated sepsis. J. Biol. Chem., 2012, 287(2): 1448-1457. https://doi.org/10.1074/jbc.M111.312702.

[30] M Yang, C H Li, L Luo, et al. Predictive model of convective heat transfer coefficient in bone micro-grinding using nanofluid aerosol cooling. Int. Commun. Heat Mass Transf., 2021, 125: https://doi.org/10.1016/j.ichea tmasstransfer.2021.105317.

[31] Y Cao, Y J Zhu, H N Li, et al. Development and performance of a novel ultrasonic vibration plate sonotrode for grinding. J. Manuf. Process, 2020, 57: 174-186. https://doi.org/10.1016/j.jmapro.2020.06.030.

[32] Z J Duan, Q G Yin, C H Li, et al. Milling force and surface morphology of 45 steel under different Al2O3 nanofluid concentrations. Int. J. Adv. Manuf. Tech., 2020, 107(3-4): 1277-1296. https://doi.org/10.1007/ s00170-020-04969-9.

[33] B K Li, W F Ding, C Y Yang, et al. Grindability of powder metallurgy nickel-base superalloy FGH96 and sensibility analysis of machined surface roughness. Int. J. Adv. Manuf. Tech., 2019, 101(9-12): 2259-2273. https://doi.org/10.1007/s00170-018-3117-0.

[34] X FWu, C H Li, Z M Zhou, et al. Circulating purification of cutting fluid: an overview. Int. J. Adv. Manuf. Tech., 2021: https://doi.org/10.1007/ s00170-021-07854-1.

[35] Y G Wang, C H Li, Y B Zhang, et al. Processing characteristics of vegetable oil-based nanofluid MQL for grinding different workpiece materials. Int. J. Pr. Eng. Man-Gt, 2018, 5(2): 327-339. https://doi.org/10.1007/ s40684-018-0035-4.

[36] P D Martino. Ways to improve biocides for metalworking fluid. Aims Microbiol, 2021, 7(1): 13-27. https://doi.org/10.3934/microbiol.2021002.

[37] WTWu, C H Li, M Yang, et al. Specific energy and G ratio of grinding cemented carbide under different cooling and lubrication conditions. Int. J. Adv. Manuf. Tech., 2019, 105(1-4): 67-82. https://doi.org/10.1007/ s00170-019-04156-5.

[38] J C Zhang, W T Wu, C H Li, et al. Convective heat transfer coefficient model under nanofluid minimum quantity lubrication coupled with cryogenic air grinding Ti-6Al-4V. Int. J. Pr. Eng. Man-Gt, 2021, 8(4): 11131135. https://doi.org/10.1007/s40684-020-00268-6.

[39] U Friis, T Menné, M-A Flyvholm, et al. Isothiazolinones in commercial products at Danish workplaces. Contact Dermatitis, 2014, 71: https://doi. org/10.1111/cod.12235.

[40] S M Guo, C H Li, Y B Zhang, et al. Experimental evaluation of the lubrication performance of mixtures of castor oil with other vegetable oils in MQL grinding of nickel-based alloy. J. Clean Prod., 2017, 140: 1060-1076. https://doi.org/10.1016/j.jclepro.2016.10.073.

[41] H Z Zheng, R L Ma, M Gao, et al. Antibacterial applications of graphene oxides: structure-activity relationships, molecular initiating events and biosafety. Sci. Bull., 2018, 63(2): 133-142. https://doi.org/10.1016/j.scib. 2017.12.012.

[42] I Sengupta, P Bhattacharya, MonikangkanaTalukdar, et al. Bactericidal effect of graphene oxide and reduced graphene oxide: Influence of shape of bacteria. Colloid Interfac. Sci., 2018, 28: 60-68. https://doi.org/ 10.1016/j.colcom.2018.12.001.

[43] B K Li, C H Li, Y B Zhang, et al. Heat transfer performance of MQL grinding with different nanofluids for Ni-based alloys using vegetable oil. J. Clean Prod., 2017, 154: 1-11. https://doi.org/10.1016/j.jclepro.2017.03. 213.

[44] J A Lemire, J J Harrison, R J Turner. Antimicrobial activity of metals: mechanisms, molecular targets and applications. Nat. Rev. Microbiol., 2013, 11(6): 371-384. https://doi.org/10.1038/nrmicro3028.

[45] S Yazdankhah, K Rudi, A Bernhoft. Zinc and copper in animal feed development of resistance and co-resistance to antimicrobial agents in bacteria of animal origin. Microb. Ecol. Health Dis., 2014, 25(1): 25862 https://doi.org/10.3402/mehd.v25.25862.

[46] M A Hayat, H M Ali, M M Janjua, et al. Phase change material/heat pipe and Copper foam-based heat sinks for thermal management of 
electronic systems. J. Energy Storage, 2020, 32: https://doi.org/10.1016/j. est.2020.101971.

[47] D L Johnson, M L Phillips. UV disinfection of soluble oil metalworking fluids. AlHA Journal, 2002, 63(2): 178-183. https://doi.org/10.1080/15428 110208984702.

[48] K Gerulova, E Buranská, O Tatarka, et al. Preliminary study of ozone utilization in elimination of bacterial contamination in metalworking fluids. Key Engineering Materials, 2014, 581: 143-147. https://doi.org/10. 4028/www.scientific.net/KEM.581.143.

[49] K Gerulova, O Tatarka, T Stefko, et al. Effect of ozone application to microbial contaminated samples of in-use metalworking fluids. Advanced Materials Research, 2014, 884: 277-282. https://doi.org/10. 4028/www.scientific.net/AMR.884-885.277.

[50] H Yamada, K Konishi, K Shimada, et al. Effect of ultrafine bubbles on pseudomonas aeruginosa and staphylococcus aureus during sterilization of machining fluid. Int. J. Auto Tech-jpn, 2021, 15(1): 99-108. https:// doi.org/10.20965/ijat.2021.p0099.

[51] K K Gajrani, M R Sankar. Past and current status of eco-friendly vegetable oil based metal cutting fluids. Materials Today: Proceedings, 2017, 4(2): 3786-3795. https://doi.org/10.1016/.jmatpr.2017.02.275.

[52] R Katna, K Singh, N Agrawal, et al. Green manufacturing — performance of a biodegradable cutting fluid. Mater. Manuf. Process, 2017, 32(13): 1522-1527.https://doi.org/10.1080/10426914.2017.1328119.

[53] T Gao, X P Zhang, C H Li, et al. Surface morphology evaluation of multi-angle 2D ultrasonic vibration integrated with nanofluid minimum quantity lubrication grinding. J. Manuf. Process, 2020, 51: 44-61. https:// doi.org/10.1016/j.jmapro.2020.01.024.

[54] P Yan, Y Rong, G Wang. The effect of cutting fluids applied in metal cutting process. P. I. Mech. Eng. B-J. Eng., 2015, 230(1): 19-37. https://doi.org/ 10.1177/0954405415590993.

[55] Q A Yin, C H Li, L Dong, et al. Effects of the physicochemical properties of different nanoparticles on lubrication performance and experimental evaluation in the NMQL milling of Ti-6Al-4V. Int. J. Adv. Manuf. Tech., 2018, 99(9): 3091-3109. https://doi.org/10.1007/s00170-018-2611-8.

[56] M Yang, C Li, Z Said, et al. Semiempirical heat flux model of hard-brittle bone material in ductile microgrinding. J. Manuf. Process, 2021, 71: 501514. https://doi.org/10.1016/j.jmapro.2021.09.053.

[57] C-M Lee, Y-H Choi, J-H Ha, et al. Eco-friendly technology for recycling of cutting fluids and metal chips: A review. Int. J. Pr. Eng. Man-Gt, 2017, 4(4): 457-468. https://doi.org/10.1007/s40684-017-0051-9.

[58] Y Y Yang, Y D Gong, C H Li, et al. Mechanical performance of $316 \mathrm{~L}$ stainless steel by hybrid directed energy deposition and thermal milling process. J. Mater. Process Tech., 2021, 291: https://doi.org/10.1016/j. jmatprotec.2020.117023.

[59] S Palanisamy, S D Mcdonald, M S Dargusch. Effects of coolant pressure on chip formation while turning Ti6Al4V alloy. Int. J. Mach. Tool Manu., 2009, 49(9): 739-743. https://doi.org/10.1016/j.jimachtools.2009.02.010.

[60] G T Smith. Cutting tool technology: Industrial handbook. Springer Science \& Business Media, 2008.

[61] M Yang, C H Li, Y B Zhang, et al. Predictive model for minimum chip thickness and size effect in single diamond grain grinding of zirconia ceramics under different lubricating conditions. Ceram. Int., 2019, 45(12): 14908-14920. https://doi.org/10.1016/..ceramint.2019.04.226

[62] M Stanford, P M Lister, C Morgan, et al. Investigation into the use of gaseous and liquid nitrogen as a cutting fluid when turning BS 970-80A15 (En32b) plain carbon steel using WC-Co uncoated tooling. J. Mater. Process Tech., 2009, 209(2): 961-972. https://doi.org/10.1016/j.jmatp rotec.2008.03.003.

[63] D Z Jia, C H Li, Y B Zhang, et al. Experimental evaluation of surface topographies of NMQL grinding $\mathrm{ZrO} 2$ ceramics combining multiangle ultrasonic vibration. Int. J. Adv. Manuf. Tech., 2019, 100(1-4): 457-473. https://doi.org/10.1007/s00170-018-2718-y.

[64] Z Said, P Sharma, L S Sundar, et al. Synthesis, stability, thermophysical properties and $\mathrm{Al}$ approach for predictive modelling of $\mathrm{Fe} 3 \mathrm{O} 4$ coated MWCNT hybrid nanofluids. J. Mol. Liq., 2021, 340: https://doi.org/10. 1016/.molliq.2021.117291.

[65] M P Groover. Fundamentals of modern manufacturing: Materials, processes, and systems. John Wiley \& Sons, 2020.

[66] M Yang, C H Li, Y B Zhang, et al. Maximum undeformed equivalent chip thickness for ductile-brittle transition of zirconia ceramics under different lubrication conditions. Int. J. Mach. Tool Manu., 2017, 122 55-65. https://doi.org/10.1016/j.jimachtools.2017.06.003.

[67] Z Said, L S Sundar, H Rezk, et al. Thermophysical properties using ND/ water nanofluids: An experimental study, ANFIS-based model and optimization. J. Mol. Liq., 2021, 330: https://doi.org/10.1016/j.molliq. 2021.115659

[68] T Gao, C H Li, M Yang, et al. Mechanics analysis and predictive force models for the single-diamond grain grinding of carbon fiber reinforced polymers using CNT nano-lubricant. J. Mater. Process Tech., 2021, 290: 116976. https://doi.org/10.1016/j.jmatprotec.2020.116976.

[69] Q A Yin, C H Li, Y B Zhang, et al. Spectral analysis and power spectral density evaluation in Al2O3 nanofluid minimum quantity lubrication milling of 45 steel. Int. J. Adv. Manuf. Tech., 2018, 97 (1-4): 129-145. https://doi.org/10.1007/s00170-018-1942-9.

[70] M H Sui, C H Li, WTWu, et al. Temperature of grinding carbide with castor oil-based MoS2 nanofluid minimum quantity lubrication. J. Therm Sci. Eng. Appl., 2021, 13(5): https://doi.org/10.1115/1.4049982.

[71] T Childs. Friction modelling in metal cutting. Wear, 2006, 260(3): 310318. https://doi.org/10.1016/j.wear.2005.01.052.

[72] V K Jain, D S Shukla. Study of the EP activity of water-soluble inorganic metallic salts for aqueous cutting fluids. Wear, 1996, 193(2): 226-234. https://doi.org/10.1016/0043-1648(95)06774-4.

[73] K Kwon, D Cho, S J Lee, et al. A fluid dynamic analysis model of the ultra-precision cutting mechanism. CIRP Ann-Manuf. Tech., 1999, 48(1): 43-46.https://doi.org/10.1016/S0007-8506(07)63128-X.

[74] C Cassin, G Boothroyd. Lubricating action of cutting fluids. J. Mech. Eng. Sci., 1965, 7(1): 67-81. https://doi.org/10.1243/JMES_JOUR_1965_007_ 012_02.

[75] A Mondelin, B Furet, J Rech. Characterisation of friction properties between a laminated carbon fibres reinforced polymer and a monocrystalline diamond under dry or lubricated conditions. Tribol. Int. 2010, 43(9): 1665-1673. https://doi.org/10.1016/j.triboint.2010.03.015.

[76] X Cui, C H Li, Y B Zhang, et al. Tribological properties under the grinding wheel and workpiece interface by using graphene nanofluid lubricant. Int. J. Adv. Manuf. Tech., 2019, 104(9): 3943-3958. https://doi.org/10.1007/ s00170-019-04129-8.

[77] T Gao, C H Li, D Z Jia, et al. Surface morphology assessment of CFRP transverse grinding using CNT nanofluid minimum quantity lubrication. J. Clean Prod., 2020, 277: 123328. https://doi.org/10.1016/j.jclepro.2020. 123328.

[78] X M Wang, C H Li, Y B Zhang, et al. Vegetable oil-based nanofluid minimum quantity lubrication turning: Academic review and perspectives. J. Manuf. Process, 2020, 59: 76-97. https://doi.org/10.1016/j.jmapro.2020. 09.044.

[79] X P Zhang, C H Li, Y B Zhang, et al. Lubricating property of MQL grinding of $\mathrm{Al} 2 \mathrm{O} 3 / \mathrm{SiC}$ mixed nanofluid with different particle sizes and microtopography analysis by cross-correlation. Precis. Eng., 2017, 47: 532-545. https://doi.org/10.1016/j.precisioneng.2016.09.016.

[80] X P Zhang, C H Li, D Z Jia, et al. Spraying parameter optimization and microtopography evaluation in nanofluid minimum quantity lubrication grinding. Int. J. Adv. Manuf. Tech., 2019, 103(5-8): 2523-2539. https:// doi.org/10.1007/s00170-019-03642-0.

[81] A Ejaz, H Babar, H M Ali, et al. Concentrated photovoltaics as light harvesters: Outlook, recent progress, and challenges. Sustain. Energy Techn., 2021, 46: https://doi.org/10.1016/j.seta.2021.101199.

[82] J C Zhang, C H Li, Y B Zhang, et al. Temperature field model and experimental verification on cryogenic air nanofluid minimum quantity lubrication grinding. Int. J. Adv. Manuf. Tech., 2018, 97(1-4): 209-228. https://doi.org/10.1007/s00170-018-1936-7.

[83] H N Li, Y J Zhao, S Cao, et al. Controllable generation of 3D textured abrasive tools via multiple-pass laser ablation. J. Mater. Process Tech., 2021, 295: 117149. https://doi.org/10.1016/j.jmatprotec.2021.117149.

[84] J Singh, S S Gill, M Dogra, et al. A review on cutting fluids used in machining processes. Engineering Research Express, 2021, 3(1): 012002. https://doi.org/10.1088/2631-8695/abeca0.

[85] D P Adler, W S Hii, D J Michalek, et al. Examining the role of cutting fluids in machining and efforts to address associated environmental/ health concerns. Mach. Sci. Technol., 2006, 10(1): 23-58. https://doi.org/ 10.1080/10910340500534282

[86] H N Li, J P Wang, C Q Wu, et al. Damage behaviors of unidirectional CFRP in orthogonal cutting: A comparison between single- and 
multiple-pass strategies. Compos. Part B-Eng., 2020, 185: 107774. https:// doi.org/10.1016/j.compositesb.2020.107774.

[87] N Talib, E A Rahim. Performance evaluation of chemically modified crude jatropha oil as a bio-based metalworking fluids for machining process. Procedia CIRP, 2015, 26: 346-350. https://doi.org/10.1016/j. procir.2014.07.155.

[88] C Mao, P H Cai, Y L Hu, et al. Effect of laser-discrete-quenching on bonding properties of electroplated grinding wheel with AISI 1045 steel substrate and nickel bond. Chinese J. Aeronaut, 2020, 34(6): 79-89. https://doi.org/10.1016/j.cja.2020.09.010.

[89] R ÁVila, A AbrãO. The effect of cutting fluids on the machining of hardened AISI 4340 steel. J. Mater. Process Tech., 2001, 119(1): 21-26. https:// doi.org/10.1016/S0924-0136(01)00891-3.

[90] S Debnath, M M Reddy, Q S Yi. Influence of cutting fluid conditions and cutting parameters on surface roughness and tool wear in turning process using Taguchi method. Measurement, 2016, 78: 111-119. https:// doi.org/10.1016/j.measurement.2015.09.011.

[91] C Mao, J Lu, Z H Zhao, et al. Simulation and experiment of cutting characteristics for single cBN-WC-10Co fiber. Precision Engineering, 2018, 52: 170-182. https://doi.org/10.1016/j.precisioneng.2017.12.001.

[92] Y J Zhao, W H Xu, C Z Xi, et al. Automatic and accurate measurement of microhardness profile based on image processing. IEEE TInstrum. Meas., 2021, 70: 1-9. https://doi.org/10.1109/TIM.2021.3067191.

[93] K K Gajrani, D Ram, M Ravi Sankar. Biodegradation and hard machining performance comparison of eco-friendly cutting fluid and mineral oil using flood cooling and minimum quantity cutting fluid techniques. J. Clean Prod., 2017, 165: 1420-1435. https://doi.org/10.1016/j.jclepro.2017. 07.217.

[94] Z L Tang. A review of corrosion inhibitors for rust preventative fluids. Curr. Opin. Solid State Mater. Sci., 2019, 23(4): 100759. https://doi.org/10. 1016/j.cossms.2019.06.003.

[95] L R Rudnick. Lubricant additives: Chemistry and applications. CRC Press, 2017.

[96] A G Talon, J C Lopes, A B Tavares, et al. Effect of hardened steel grinding using aluminum oxide wheel under application of cutting fluid with corrosion inhibitors. Int. J. Adv. Manuf. Tech., 2019, 104(1): 1437-1448. https://doi.org/10.1007/s00170-019-04005-5.

[97] O S I Fayomi, P A L Anawe, A Daniyan. The impact of drugs as corrosion inhibitors on aluminum alloy in coastal-acidified medium. Corrosion Inhibitors, Principles and Recent Applications 1st ed Rijeka: InTech Open, 2018: 79-94. https://doi.org/10.5772/intechopen.72942.

[98] A G Talon, J C Lopes, B K Sato, et al. Grinding performance of hardened steel: a study about the application of different cutting fluids with corrosion inhibitor. Int. J. Adv. Manuf. Tech., 2020, 108(9): 2741-2754. https:// doi.org/10.1007/s00170-020-05598-y.

[99] E Kuram, B Ozcelik, M Bayramoglu, et al. Optimization of cutting fluids and cutting parameters during end milling by using D-optimal design of experiments. J. Clean Prod., 2013, 42(mar.): 159-166. https://doi.org/ 10.1016/j.jclepro.2012.11.003.

[100] E Kuram, B Ozcelik, E Demirbas. Environmentally friendly machining: vegetable based cutting fluids. In: Green manufacturing processes and systems. Springer, 2013: 23-47. https://doi.org/10.1007/ 978-3-642-33792-5_2.

[101] K Wickramasinghe, H Sasahara, E Abd Rahim, et al. Green metalworking fluids for sustainable machining applications: A review. J. Clean Prod., 2020, 257: 120552. https://doi.org/10.1016/j.jclepro.2020.120552.

[102] H-C Flemming, JWingender. The biofilm matrix. Nat. Rev. Microbiol., 2010, 8(9): 623-633. https://doi.org/10.1038/nrmicro2415

[103] J L Shennan. Selection and evaluation of biocides for aqueous metalworking fluids. Tribol. Int., 1983, 16(6): 317-330. https://doi.org/10.1016/ 0301-679X(83)90042-7.

[104] P Giovanella, G A Vieira, IV R Otero, et al. Metal and organic pollutants bioremediation by extremophile microorganisms. J. Hazard Mater. 2020, 382: 121024. https://doi.org/10.1016/j.jhazmat.2019.121024.

[105] C Gram. Ueber die isolirte Farbung der Schizomyceten in Schnitt-und Trockenpraparaten. Fortschritte der Medicin, 1884, 2: 185-189. https://doi. org/10.1055/s-0029-1209285.

[106] R Saha, R S Donofrio. The microbiology of metalworking fluids. Appl. Microbiol. Biot., 2012, 94(5):1119-1130. https://doi.org/10.1007/ s00253-012-4055-7
[107] N Di Maiuta, A Rüfenacht, P Küenzi. Assessment of bacteria and archaea in metalworking fluids using massive parallel 165 rRNA gene tag sequencing. Lett. Appl. Microbiol., 2017, 65(4): 266-273. https://doi.org/ 10.1111/lam.12782.

[108] N Lodders, P Kämpfer. A combined cultivation and cultivation-independent approach shows high bacterial diversity in water-miscible metalworking fluids. Syst. Appl. Microbiol., 2012, 35(4): 246-252. https:// doi.org/10.1016/j.syapm.2012.03.006.

[109] A Rabenstein, T Koch, M Remesch, et al. Microbial degradation of water miscible metal working fluids. Int. Biodeter Biodegr, 2009, 63(8): 10231029. https://doi.org/10.1016/j.ibiod.2009.07.005

[1 10] Y Gilbert, M Veillette, C Duchaine. Metalworking fluids biodiversity characterization. J. Appl. Microbiol, 2010, 108(2): 437-449. https://doi.org/10. 1111/j.1365-2672.2009.04433.x.

[111] M Sandin, I Mattsby-Baltzer, L Edebo. Control of microbial growth in water-based metal-working fluids. International Biodeterioration, 1991 , 27(1): 61-74. https://doi.org/10.1016/0265-3036(91)90024-L.

[112] C Gast, C J Knowles, M A Wright, et al. Identification and characterisation of bacterial populations of an in-use metal-working fluid by phenotypic and genotypic methodology. Int. Biodeter Biodegr, 2001, 47(2): 113-123. https://doi.org/10.1016/S0964-8305(01)00036-1.

[113] J S Moore, M Christensen, RW Wilson, et al. Mycobacterial contamination of metalworking fluids: involvement of a possible new taxon of rapidly growing mycobacteria. AlHAJ, 2000, 61(2): 205-213. https://doi. org/10.1080/15298660008984529.

[114] R Kapoor, I S Yadav. Expanding the mycobacterial diversity of metalworking fluids (MWFs): Evidence showing MWF colonization by Mycobacterium abscessus. FEMS Microbiol. Ecol., 2012, 79(2): 392-399. https://doi.org/10.1111/j.1574-6941.2011.01227.X.

[115] RW Wilson, V A Steingrube, E C Böttger, et al. Mycobacterium immunogenum sp. nov., a novel species related to Mycobacterium abscessus and associated with clinical disease, pseudo-outbreaks and contaminated metalworking fluids: an international cooperative study on mycobacterial taxonomy. Int. J. Syst. Evol. Micr., 2001, 51(5): 1751-1764. https://doi.org/10.1099/00207713-51-5-1751.

[116] C M Burton, B Crook, H Scaife, et al. Systematic review of respiratory outbreaks associated with exposure to water-based metalworking fluids. Ann. Occup. Hyg., 2012, 56(4): 374-388. https://doi.org/10.1093/ annhyg/mer121.

[117] JT Bonner, D S Lamont. Behavior of cellular slime molds in the soil. Mycologia, 2005, 97(1): 178-184. https://doi.org/10.1080/15572536. 2006.11832851.

[118] T Mang. Encyclopedia of lubricants and lubrication. Springer Berlin Heidelberg, 2014

[119] A Bridier, R Briandet, VThomas, et al. Resistance of bacterial biofilms to disinfectants: A review. Biofouling, 2011, 27(9): 1017-1032. https://doi. org/10.1080/08927014.2011.626899.

[120] HVan Acker, P Van Dijck, T Coenye. Molecular mechanisms of antimicrobial tolerance and resistance in bacterial and fungal biofilms. Trends Microbiol, 2014, 22(6): 326-333. https://doi.org/10.1016/j.tim.2014.02. 001.

[121] F J Passman, P Küenzi. Microbiology in water-miscible metalworking fluids. Tribol. T., 2020, 63(6): 1147-1171. https://doi.org/10.1080/10402 004.2020 .1764684$.

[122] S Ma, K Kim, J Huh, et al. Regeneration and purification of water-soluble cutting fluid through ozone treatment using an air dielectric barrier discharge. Sep Purif Technol., 2018, 199: 289-297. https://doi.org/10. 1016/j.seppur.2018.02.005.

[123] P Piccardi, B Vessman, S Mitri. Toxicity drives facilitation between 4 bacterial species. Proceedings of the National Academy of Sciences, 2019, 116(32): 15979-15984. https://doi.org/10.1073/pnas.1906172116.

[124] A De Groot, J Geier, M A Flyvholm, et al. Formaldehyde-releasers: relationship to formaldehyde contact allergy. Metalworking fluids and remainder. Part 1. Contact Dermatitis, 2010, 63(3): 117-128. https://doi. org/10.1111/j.1600-0536.2009.01582.x.

[125] P Dantigny, S P-M Nanguy. Significance of the physiological state of fungal spores. Int. J. Food Microbiol., 2009, 134(1-2): 16-20. https://doi. org/10.1016/j.ijfoodmicro.2009.02.005.

[126] H Beyenal, J Babauta. Microscale gradients and their role in electrontransfer mechanisms in biofilms. Biochem. Soc. T., 2012, 40(6): 1315. https://doi.org/10.1042/BST20120105. 
[127] A J Wolfe. Glycolysis for the microbiome generation. Metabolism and Bacterial Pathogenesis, 2015: 1-16. https://doi.org/10.1128/microbiols pec.MBP-0014-2014.

[128] B F Gilmore. Antimicrobial ionic liquids. INTECH Open Access Publisher, 2011.

[129] S S Tay, B Roediger, P L Tong, et al. The skin-resident immune network. Curr. Dermatol. Rep., 2014, 3(1): 13-22. https://doi.org/10.1007/ s13671-013-0063-9

[130] C E Boorsma, C Draijer, B N Melgert. Macrophage heterogeneity in respiratory diseases. Mediat. Inflamm., 2013: https://doi.org/10.1155/ 2013/769214.

[131] J-M Cavaillon. Exotoxins and endotoxins: Inducers of inflammatory cytokines. Toxicon, 2018, 149: 45-53. https://doi.org/10.1016/j.toxicon. 2017.10.016.

[132] E Hamed, N Saker, S ElShazly, et al. Synthesis of antibacterial additive for metal working fluids application. MATEC Web of Conferences, 2018, 162: 05011. https://doi.org/10.1051/matecconf/201816205011

[133] P Maris. Modes of action of disinfectants. Rev. Sci. Tech. Oie., 1995, 14(1): 47-55. https://doi.org/10.20506/rst.14.1.829.

[134] D P Gnanadhas, S A Marathe, D Chakravortty. Biocides-resistance, crossresistance mechanisms and assessment. Expert Opin. Inv. Drug, 2013, 22(2): 191-206. https://doi.org/10.1517/13543784.2013.748035.

[135] S Forbes, C G Knight, N L Cowley, et al. Variable effects of exposure to formulated microbicides on antibiotic susceptibility in firmicutes and proteobacteria. Appl. Environ. Microb., 2016, 82(12): 3591. https://doi. org/10.1128/AEM.00701-16.

[136] E S Park, W S Moon, M J Song, et al. Antimicrobial activity of phenol and benzoic acid derivatives. Int. Biodeter Biodegr, 2001, 47(4): 209-214 https://doi.org/10.1016/S0964-8305(01)00058-0.

[137] E R Kenawy, S Worley, R Broughton. The chemistry and applications of antimicrobial polymers: A state-of-the-art review. Biomacromolecules, 2007, 8(5): 1359-1384. https://doi.org/10.1021/bm061150q

[138] A Alamri, M H El-Newehy, S S Al-Deyab. Biocidal polymers: synthesis and antimicrobial properties of benzaldehyde derivatives immobilized onto amine-terminated polyacrylonitrile. Chem. Cent. J., 2012, 6(1): 111. https://doi.org/10.1186/1752-153X-6-111.

[139] J G Xiang, X H Qi, J J Xin, et al. Development of multifunctional long-life extreme pressure emulsified cutting fluid. Lubrication Engineering, 2015, 40(06): 104-110, 132. https://doi.org/10.3969/j.issn.0254-0150.2015.06. 021.

[140] W Li, T Ma, S Wang, et al. Borate ester and its applications in waterbased cutting fluid. Tool Engineering, 2010, 44(05): 93-95. https://doi. org/10.16567/j.cnki.1000-7008.2010.05.019.

[141] S N Bi, J C Zhong, Y Qi, et al. Latest research progress and industrialization trend of boron-containing chemicals such as boric acid. Inorganic Chemicals Industry, 2020, 52(01): 5-8. https://doi.org/10.11962/10064990.2019-0601.

[142] S M John, J D Johansen, T Rustemeyer, et al. Kanerva's occupational dermatology. Springer, 2020

[143] W Paulus. Microbicides for the protection of materials: A handbook Springer Science \& Business Media, 2012

[144] J Q Fu. The normal disinfection and sterilization and its mechanism and application. Liquor-making Science \& Technology, 1999, (02): 87-89, 91. https://doi.org/10.13746/j.njkj.1999.02.038.

[145] GY Li, C H Li, M M Zhang, et al. Research on the effects of compound bactericides on anti-microbial performance of water-based cutting fluid. Chemistry and Adhesion, 2015, 37(02): 85-90, 145. CNKI:SUN:HXYZ.0.2015-02-002.

[146] Z Recai, I Hubbezoglu, A OZDEMIR, et al. Antibacterial effect of different concentration of boric acid against enterococcus faecalis biofilms in root canal. Marmara Dental Journal, 2013, 1(2): 76-80. https://doi.org/10 12990/MDJ.201317716.

[147] K Sasaki, X Qiu, S Moriyama, et al. Characteristic sorption of H3BO3/ B(OH) 4 - on magnesium oxide. Mater. Trans., 2013, 54(9): 1809-1817. https://doi.org/10.2320/matertrans.M-M2013814.

[148] N Latorre, J Silvestre, A Monteagudo. Allergic contact dermatitis caused by formaldehyde and formaldehyde releasers. Actas Dermo-Sifiliográfcas (English Edition), 2011, 102(2): 86-97. https://doi.org/10.1016/S15782190(11)70765-X.

[149] A De Groot, I R White, M A Flyvholm, et al. Formaldehyde-releasers in cosmetics: relationship to formaldehyde contact allergy: Part 2. Patch test relationship to formaldehyde contact allergy, experimentalprovocation tests, amount of formaldehyde released, and assessment of risk to consumers allergic to formaldehyde. Contact Dermatitis, 2010, 62(1): 18-31. https://doi.org/10.1111/j.1600-0536.2009.01631.x.

[150] G Kapoor, S Saigal, A Elongavan. Action and resistance mechanisms of antibiotics: A guide for clinicians. J. Anaesth Clin Pharm, 2017, 33(3): 300305. https://doi.org/10.4103/joacp.JOACP_349_15.

[151] A A Abd-Elaal, N A Negm, G Biresaw, et al. Silver nanoparticles colloidal dispersions: Synthesis and antimicrobial activity. In: Surfactants in tribology. CRC Press, 2017: 149-171. Doi: https://doi.org/10.1201/9781315120 829-10.

[152] J P Ruparelia, A K Chatterjee, S P Duttagupta, et al. Strain specificity in antimicrobial activity of silver and copper nanoparticles. Acta Biomater, 2008, 4(3): 707-716. https://doi.org/10.1016/j.actbio.2007.11.006.

[153] J Blair, M A Webber, A J Baylay, et al. Molecular mechanisms of antibiotic resistance. Nat. Rev. Microbiol., 2015, 13(1): 42-51. https://doi.org/10. 1038/nrmicro3380

[154] STavakoli, S Nemati, M Kharaziha, et al. Embedding CuO nanoparticles in PDMS-SiO2 coating to improve antibacterial characteristic and corrosion resistance. Colloid Interface Sci, 2019, 28: 20-28. https://doi.org/10. 1016/j.colcom.2018.11.002.

[155] I Sondi, B Salopek-Sondi. Silver nanoparticles as antimicrobial agent: a case study on E. coli as a model for Gram-negative bacteria. J. Colloid. Interf. Sci., 2004, 275(1): 177-182. https://doi.org/10.1016/j.jcis.2004.02. 012

[156] B Bernardo, M L Cacicedo, á V A, et al. Self-assembly stereo-specific synthesis of silver phosphate microparticles on bacterial cellulose membrane surface for antimicrobial applications. Colloid. Interface Sci., 2018, 26: 7-13. https://doi.org/10.1016/.j.colcom.2018.07.002.

[157] X B Qi, P Gunawan, R Xu, et al. Cefalexin-immobilized multi-walled carbon nanotubes show strong antimicrobial and anti-adhesion properties. Chem. Eng. Sci., 2012, 84: 552-556. https://doi.org/10.1016/j.ces, 2012.08.054.

[158] S Suresh, S Karthikeyan, P Saravanan, et al. Comparison of antibacterial and antifungal activities of 5-amino-2-mercaptobenzimidazole and functionalized $\mathrm{NiO}$ nanoparticles. Karbala International Journal of Modern Science, 2016, 2(3): 188-195. https://doi.org/10.1016/j.kijoms. 2016.05.001.

[159] S Simon. Bacterial silver resistance: molecular biology and uses and misuses of silver compounds. Fems. Microbiol. Rev., 2003, 27(2-3): 341-353. https://doi.org/10.1016/50168-6445(03)00047-0.

[160] C N Lok, C M Ho, R Chen, et al. Proteomic analysis of the mode of antibacterial action of silver nanoparticles. J. Proteome. Res., 2006, 5(4): 916-924. https://doi.org/10.1021/pr0504079.

[161] C Khca, B Jep, B To, et al. The study of antimicrobial activity and preservative effects of nanosilver ingredient - ScienceDirect. Electrochim Acta, 2005, 51(5): 956-960. https://doi.org/10.1016/j.electacta.2005.04. 071.

[162] G Zhao, SE Stevens. Multiple parameters for the comprehensive evaluation of the susceptibility of Escherichia coli to the silver ion. Biometals, 1998, 11(1): 27-32. https://doi.org/10.1023/A:1009253223055.

[163] A Nasrollahi, K Pourshamsian, P Mansourkiaee. Antifungal activity of silver nanoparticles on some of fungi. Int. J. Nano Dimens., 2010, 1: https:// doi.org/10.7508/ijnd.2010.03.007.

[164] H H Lara, D G Romero-Urbina, C Pierce, et al. Effect of silver nanoparticles on Candida albicans biofilms: an ultrastructural study. J. Nanobiotechnol, 2015, 13(1): 1-12. https://doi.org/10.1186/s12951-015-0147-8.

[165] A Ogar, G Tylko, KTurnau. Antifungal properties of silver nanoparticles against indoor mould growth. Sci. Total Environ., 2015, 521: 305-314. https://doi.org/10.1016/.scitotenv.2015.03.101.

[166] M Monerris, M F Broglia, E I Yslas, et al. Highly effective antimicrobial nanocomposites based on hydrogel matrix and silver nanoparticles: long-lasting bactericidal and bacteriostatic effects. Soft Matter, 2019, 15(40): 8059-8066. https://doi.org/10.1039/C9SM01118H.

[167] V C Verma, R N Kharwar, A C Gange. Biosynthesis of antimicrobial silver nanoparticles by the endophytic fungus Aspergillus clavatus. Nanomedicine, 2010, 5(1): 33-40. https://doi.org/10.2217/nnm.09.77.

[168] S Chan, M Don. Characterization of Ag nanoparticles produced by white-rot fungi and its in vitro antimicrobial activities. International Arabic Journal of Antimicrobial Agents, 2012, 2(3:3): 1-8. https://doi.org/ 10.3823/717. 
[169] S Suresh, S Karthikeyan, P Saravanan, et al. Comparison of antibacterial and antifungal activity of 5-amino-2-mercapto benzimidazole and functionalized Ag3O4 nanoparticles. Karbala International Journal of Modern Science, 2016, 2(2): 129-137. https://doi.org/10.1016/j.kijoms. 2016.03.003.

[170] P Devi, S D Patil, P Jeevanandam, et al. Synthesis, characterization and bactericidal activity of silica/silver core-shell nanoparticles. J. Mater. Sci-Mater M, 2014, 25(5): 1267-1273. https://doi.org/10.1007/ s10856-014-5165-9.

[171] M Arshad, A Qayyum, G A Shar, et al. Zn-doped SiO 2 nanoparticles preparation and characterization under the effect of various solvents: Antibacterial, antifungal and photocatlytic performance evaluation. J. Photoch Photobio B, 2018, 185: 176-183. https://doi.org/10.1016/j.jphot obiol.2018.04.043.

[172] C H Hu, M S Xia. Adsorption and antibacterial effect of copperexchanged montmorillonite on Escherichia coli K88. Appl. Clay Sci., 2006, 31(3-4): 180-184. https://doi.org/10.1016/j.clay.2005.10.010.

[173] A Esteban-Cubillo, C Pecharromán, E Aguilar, et al. Antibacterial activity of copper monodispersed nanoprticles into sepiolite. J. Mater. Sci., 2006, 41(16): 5208-5212. https://doi.org/10.1007/s10853-006-0432-x.

[174] K Kitamoto, K Yoshizawa, Y Ohsumi, et al. Dynamic aspects of vacuolar and cytosolic amino acid pools of Saccharomyces cerevisiae. J. Bacteriol, 1988, 170(6): 2683-2686. https://doi.org/10.1128/jb.170.6.2683-2686. 1988.

[175] N Hoshino, T Kimura, F Hayakawa, et al. Bactericidal activity of catechincopper (II) complexes against Staphylococcus aureus compared with Escherichia coli. Lett. Appl. Microbiol., 2010, 31(3): 213-217. https://doi. org/10.1046/j.1365-2672.2000.00800.x.

[176] C Ramesh, M Hariprasad, V Ragunathan. Antibacterial behaviour of Cu2O Nanoparticles Against Escherichia coli; Reactivity of Fehling's Solution on Manihot esculenta Leaf Extract. Curr. Nanosci., 2011, 7(5): 770-775. https://doi.org/10.2174/157341311797483763.

[177] A P Fraise, J Y Maillard, S Sattar. Russell, Hugo \& Ayliffe's principles and practice of disinfection, preservation \& sterilization. Blackwell Pub., 2013.

[178] A Tronsmo, T Gjøen, H Sørum, et al. Antimicrobial resistance due to the use of biocides and heavy metals: A literature review. 2016: https://hdl. handle.net/10037/19588.

[179] J Li, G Y Ren, Y Zhang, et al. Two Cu(II) complexes of 1,2,4-triazole fungicides with enhanced antifungal activities. Polyhedron, 2018, 157: 163-169. https://doi.org/10.1016/j.poly.2018.09.052

[180] V Farzaliyev, M Bayramov, J S Kh, et al. Metal complex compounds as effective additives to cutting fluids. Kim. Probl., 2019, (1): https://doi.org/ 10.32737/2221-8688-2019-1-81-86.

[181] P A Fatullayeva. Complexes of metals with dihydrazones of succinic acid dihydrazide. Kim. Probl., 2019, (4): https://doi.org/10.32737/ 2221-8688-2019-4-558-564.

[182] A Rahimova, M P Sh, T llyasly, et al. Synthesis and antimicrobial properties of n, n-bis-(p-dimethylaminobenzylidene) diaminopropane and its metal complexes. Azerb Khim Zh, 2016, (1): http://bibliotecatede.unino ve.br/handle/tede/2211

[183] L H Abdel-Rahman, A M Abu-Dief, R M El-Khatib, et al. Some new nanosized Fe (II), Cd (II) and Zn (II) Schiff base complexes as precursor for metal oxides: Sonochemical synthesis, characterization, DNA interaction, in vitro antimicrobial and anticancer activities. Bioorg. Chem., 2016, 69: 140-152. https://doi.org/10.1016/.jbioorg.2016.10.009.

[184] [185] V A Agertt, P C Bonez, G G Rossi, et al. Identification of antimicrobial activity among new sulfonamide metal complexes for combating rapidly growing mycobacteria. BioMetals, 2016, 29(5): 807-816. https:// doi.org/10.1007/s10534-016-9951-3.

[185] Q-M Hasi, Y Fan, X-Q Yao, et al. Synthesis, characterization, antioxidant and antimicrobial activities of a bidentate Schiff base ligand and its metal complexes. Polyhedron, 2016, 109: 75-80. https://doi.org/10. 1016/j.poly.2016.01.052.

[186] J R Anacona, K Ruiz, M Loroño, et al. Antibacterial activity of transition metal complexes containing a tridentate NNO phenoxymethylpenicillin-based Schiff base. An anti-MRSA iron (II) complex. Appl Organomet Chem, 2019, 33(4): e4744. https://doi.org/10.1002/aoc.4744.

[187] B Malik, R Maurya, J Mir, et al. Cobalt (II) bactericidal and heat resistant complexes of ONS donor schiff base ligands: synthesis and combined DFT-experimental characterization. Int. J. Curr. Res. Chem. Pharm. Sci., 2016, 3(4): 50-72. http://s-o-i.org/1.15/ijcrcps-2016-3-4-6.
[188] M J Davies. Singlet oxygen-mediated damage to proteins and its consequences. Biochem. Bioph. Res. Co., 2003, 305(3): 761-770. https://doi.org/ 10.1016/S0006-291X(03)00817-9.

[189] D I Pattison, M J Davies. Actions of ultraviolet light on cellular structures. In: Cancer: Cell structures, carcinogens and genomic instability. Basel: Birkhäuser Basel, 2006: 131-157. https://doi.org/10. 1007/3-7643-7378-4 6

[190] J Cadet, T Douki. Formation of UV-induced DNA damage contributing to skin cancer development. Photoch. Photobio. Sci., 2018, 17(12): 18161841. https://doi.org/10.1039/C7PP00395A.

[191] N Madanchi, S Thiede, C Herrmann. Functional and environmental evaluation of alternative disinfection methods for cutting fluids. Procedia CIRP, 2017, 61: 558-563. https://doi.org/10.1016/j.procir.2016.11.175.

[192] N Bono, F Ponti, C Punta, et al. Effect of UV irradiation and TiO2-photocatalysis on airborne bacteria and viruses: An overview. Materials, 2021, 14(5): https://doi.org/10.3390/ma14051075.

[193] G L V Souza. Avaliação dos ganhos econômicos e ambientais da aplicação de radiação ultravioleta para o controle de contaminação microbiológica de fluido de corte: experimento no setor de usinagem. 2019: http://bibliotecatede.uninove.br/handle/tede/2211.

[194] M Weigel Kris, K Nguyen Felicia, R Kearney Moira, et al. Molecular viability testing of UV-inactivated bacteria. Appl. Environ. Microb., 2017, 83(10): e00331-00317. https://doi.org/10.1128/AEM.00331-17.

[195] [196] O Hirofumi. The characteristics and possibilities of micro bubble technology. Shigen-to-Sozai, 2007, 123(3): 89-96. https://doi.org/10. 2473/journalofmmij.123.89.

\section{Submit your manuscript to a SpringerOpen ${ }^{\circ}$ journal and benefit from:}

- Convenient online submission

- Rigorous peer review

- Open access: articles freely available online

- High visibility within the field

- Retaining the copyright to your article

Submit your next manuscript at $\boldsymbol{\nabla}$ springeropen.com 